\title{
Depoimentos dos coordenadores e diretores do LAPEX
}

Entrevistado: médico Eduardo Henrique de Rose

Data de nascimento: 08/08/1 942 Entrevistadora: Profa. Janice Zarpellon Mazo Data da entrevista: 22/08/1 997

Transcritor: Marcelo Gomes Virginio, acadêmico do curso de Licenciatura em Educação Física da UFRGS

Pergunta - Como surgiu a idéia de criar o LAPEX?

Resposta - Em 1971 foi que eu tive a idéia de fazer o LAPEX, porque eu fui a um estágio técnico no Rio de Janeiro, do ACISME, que é a Academia Internacional Militar. É uma academia que reúne todos os militares do mundo inteiro que desenvolvem Educação Física e Medicina do Esporte; e nesse estágio da ACISME veio o professor Cooper, veio o professor Rasch, veio uma série de grandes professores do mundo. E aí eu, o coronel Teixeira, que era na época o diretor da Divisão de Educação Física e Desportos do MEC, chamava DED/MEC, numa palestra que casualmente eu acho que só estavam eu e mais três -porque era uma noite que tinha ensaio na Mangueira, e convidaram o pessoal para ir para Mangueira, mas eu preferi ver a linha do coronel- ele mostrou quais eram os planos do Brasil na área de Educação Física. Segundo ele, o Brasil tinha uma carência na área do esporte, porque não havia Ciência do Esporte, não havia Medicina do Esporte, e a inexistência dessas duas áreas trazia sérios problemas para o esporte competitivo. Então, no sentido de resolver essa carência, o DED apresentou a possibilidade de criar cinco centros brasileiros de Medicina do Esporte e Ciência do Esporte que seriam alocados nas escolas de Educação Física; e, evidentemente, o primeiro deles era no Rio, já era dirigido pelo professor Maurício Rocha; o

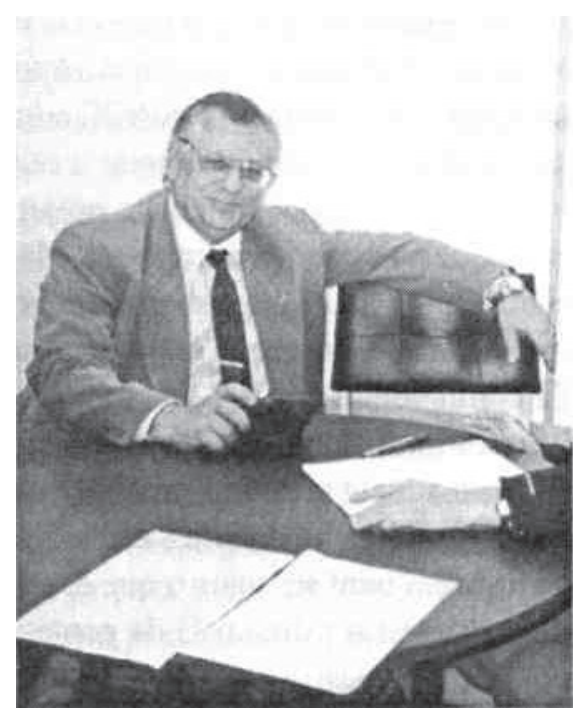

EduARdo Henrique de Rose é Médico graduado pela Faculdade Federal Fundação Ciências Médicas em 1966. Especialista em Medicina do Esporte pela ESEF/UFRGS em 1968. Professor da ESEF nas disciplinas de Socorros de Urgência e Fisiologia do Exercício em 1969. Quando a ESEF foi federalizada, em 1970, foi incorporado ao seu quadro de pessoal como médico. Curso de Especialização na Universidade de Tourse (França). Curso de Doutorado na Universidade de Colônia (Alemanha). Foi coordenador do LAPEX no periodo de 1973 a 1980. Atualmente é professor titular aposentado da Escola de Educação Física da UFRGS.

segundo era em São Paulo; e eles iam definir onde seriam os próximos três centros. Então me deu o "cutuco" que eu estando aqui parado sem fazer nada, quer dizer, eu estava de médico da Escola, não podia lecionar porque não era mais professor, já era federal, não é? Então resolvi criar, por que não? Vamos fazer esse LAPEX. A quantidade em dinheiro seria o equivalente, hoje, a um milhão e meio de dólares: eu estimo uma boa possibilidade. Vim aqui e falei com o Jorge Furtado, que era o Coordenador Acadêmico -que corresponde hoje ao que seria o Pró-Reitor de Graduação- e ele me deu apoio. Era uma pessoa que eu conhecia muito bem. Falei com o reitor, que era o Jobim; com o diretor da Escola, o coronel Targa; e todos eles disseram que a idéia era excelente. Então fiz um projeto para concorrer a isso, não é? E, 
nesse projeto, até porque eu não tinha muita experiência nisso, pedi um auxílio para o professor Mário Rigato. Então trabalhei com o professor Mário Rigato, e montamos um projeto em que pedíamos os equipamentos básicos, alguns deles ainda no LAPEX, como a esteira, o espirômetro de 600 litros; e realmente o projeto ganhou. Foi o melhor projeto e era por estado. Eu concorri com Santa Maria, ganhei de Santa Maria; e o Laboratório veio para Porto Alegre e aí começou assim: começou em 1971 com a idéia; em 1972, com o projeto, já marcamos uma inauguração que foi em agosto de 72 com aquela primeira salinha, que fica lá no ginásio. Só tinha aquela salinha do canto, onde hoje é... nem sei mais o que é, mas eram as duas primeiras salinhas lá da ponta.

P - Onde hoje é o setor de biomecânica?

$\mathrm{R}$ - É, exatamente. É a porta que desce da escada; só aquelas duas: ali eram o meu escritório e a sala de reuniões do LAPEX. Eu até tenho várias fotos disso que eu estou separando lá para te dar depois. Então a minha primeira providência, já que eu era um diretor sem ninguém dentro, foi contratar uma secretária. O LAPEX tinha uma verba específica do LAPEX: ela não vinha para a Escola, não é? Isso criou muito problema para o LAPEX; porque, evidentemente, imagina, era uma Escola pobre, não tinha material nenhum, e de repente tinham duas salinhas com um milhão e meio de dólares para montar, quer dizer, foi uma confusão tremenda. Mas dentro do padrão eu consegui evitar maiores problemas e então pedi à Escola que selecionasse os dez melhores alunos para eu poder começar o LAPEX dessa maneira. O professor Werner dos Reis que selecionou junto com o professor Targa, e desses primeiros dez eu fiz um núcleo e comecei a trabalhar com eles. Eram alunos como vocês, então comecei a definir funções: tu vais fazer fisiologia; tu, cineantropometria; tu, psiquiatria; psicologia; distribuí o que eu achava, não é? Que, aliás, eu nem tinha como achar. Então, em 1973, eu fui para os Estados Unidos e passei três meses lá visitando vários centros desse tipo em busca de referências para ter uma idéia do que era, não é? Então, a partir de 1973 nós fizemos um primeiro curso do pessoal no Rio de Janeiro. O professor Maurício Rocha treinou o doutor Belmar de Andrade, que era um médico que trabalhou desde o começo comigo, era da primeira equipe. Desses dez ainda têm aqui... ficaram ainda na Escola até agora o professor Guimarães, o professor Ricardo, foram dois desses dez; e o professor Adroaldo, que foi um desses dez mas saiu daqui. E os outros continuaram: formaram-se e continuaram trabalhando no LAPEX, ainda que não como professores. Nós só passamos a ser federalizados como professores em 1980; então, entre 1973 e 1977, eles eram contratados pelo LAPEX: tinham um contrato, que era renovado todos os anos, e não tinham estabilidade. Então eles eram chamados professores colaboradores, mas nenhum de nós podia participar do ensino na Escola. Então, os alunos reclamavam, porque o LAPEX não tinha nada a ver com o ensino. Nós não éramos professores da Escola: nós tínhamos um projeto e éramos pagos pelo Ministério, não pela Escola nem pela Universidade. Em 1980, a lei estabilizou professores com mais de tantos anos, e nós tínhamos esses anos; então todo mundo passou a ser professor da Instituição. Então, nesse período, o que eu fiz foi dividir professores, parte pela sua origem, como o professor Guimarães, que vinha da Arquitetura. Ele fazia Arquitetura antes de fazer Educação Física; ele saiu da Arquitetura para a Educação Física, então ele era o único que eu tinha que sabia fazer conta, porque ele tinha cálculo I, cálculo II. O mais difícil eu dava para ele, que era a cineantropometria, que tinha muito cálculo. Naquela época não tinha computador que nem o que tem hoje, então nós tínhamos que fazer os cálculos, a maioria à mão, ou com calculadora. Um dos primeiros equipamentos que eu comprei no LAPEX foi uma enorme calculadora Olliveti, que funcionava com cartão magnético e era programável; e tinha uma máquina de escrever como aquela ali, antiga, mecânica, com uma impressora de saída. Desde os anos 70, então, nós usávamos em todos os relatórios do LAPEX, que eram informativos, e nas primeiras pesquisas que nós fizemos no Brasil, como o projeto ANTROPOJEBS, que foi um dos projetos que nos promoveram muito. Eu comecei 
a trazer pessoas de fora, como o Ross e o Carter, para nos assessorarem e transmitirem tecnologia, por exemplo. Então nós analisamos todos os JEBs (Jogos Escolares Brasileiros) buscando padrões; e nesses padrões descobrimos um ou dois atletas que foram padrões internacionais, depois de referência, como Robson Caetano. Ele foi descoberto aqui no LAPEX dentro de um JEBs, e nós investimos nele dentro de biótipos e de capacidade física; dali em diante ele saiu para o esporte olímpico. Até tem um livro meu que traz uma foto dele com dezesseis anos sendo analisado no LAPEX, que é um livro de cineantropometria que é a Enciclopede of Sports Medicine, publicado em 1996 pela Oxford de... como é o nome da editora? Black Wheel, de Oxford. Ali eu tenho um capítulo seis, se eu não me engano, o artigo que eu escrevi; e tu vais ver uma foto do Joaquim Cruz com dezesseis anos sendo analisado aqui no estudo antropométrico. Esse livro tem na biblioteca. O Benno ficou na área de Psicologia desde o começo; ele era professor de Educação Física depois de treinado no LAPEX em Psicologia. É que nós o convencemos a fazer Psicologia, mas ele sempre foi professor de Educação Física. Ah! O Fortuna entrou logo em seguida, ele não era dos dez primeiros, mas entrou logo em seguida junto com o Biazús. O Jorge Pinto entrou logo em seguida também, não era dos dez primeiros, mas foi o segundo grupo que entrou junto com o Fortuna, o Biazús, o Jorge Pinto. Então o Jorge ficou com a fisiologia, que tinha muita facilidade para essa área por ser da área de Medicina. Nós mais ou menos traçamos um perfil que gostaríamos de ter. Os nossos monitores, como nós chamávamos, deveriam ser pessoas que tivessem noção do esporte -não precisava ter ciência: ciência ele aprendia ali- noção do esporte e noção do idioma estrangeiro. Esses foram os que começaram o LAPEX, praticamente. Dos que estão aqui hoje, o Belmar, o Jorge, o Guima, o Ricardo, o Biazús e o Fortuna; e o Adroaldo saiu e voltou cinco ou seis anos depois, já não voltou para o LAPEX, mas foi daquele primeiro grupo. Eu trabalhei no LAPEX praticamente até o momento em que senti a necessidade de sair para o doutorado, e talvez isso te responda por que eu fiquei tanto tempo na coordenação do LAPEX: primeiro porque eu fiz um regimento em que só eu podia ser o coordenador -eu fui inteligente nesse ponto; em segundo porque, claro, aqui é uma Escola de Educação Física, e tu tens que aprender toda uma estrutura de Escola. Num sistema desses, aos cinco minutos do segundo tempo ia ser substituído, mas a minha idéia era de que o projeto dependia da continuidade do recurso, não é? E na hora que eu fosse substituído terminaria o projeto, porque não tinha gente com essa estrutura internacional e nacional para captação de recursos, que eram importantes para o projeto. Então o nosso pessoal fez estágio na Suécia e fazia estágio nos melhores centros do mundo, ia para todos os congressos, quer dizer, era um pessoal muito diferenciado. Então o meu receio não era o pessoal do centro, do Laboratório, mas o pessoal da Escola; pois de repente eles me põe um professor que me mata o serviço, entende? Então eu botei uma norminha no regimento, que o coordenador do LAPEX tem que ser médico especializado em Educação Física e Desportos: só tinha eu. Ah! Não tinha como, por isso que eu durei tanto tempo. Mas aí, quando eu saí para o doutorado, entrou o Belmar dentro do mesmo sistema, que foi o segundo coordenador; depois entrou o Jorge. Mas aí mais tarde mudaram o regimento; até mudei quando eu era diretor da Escola, porque achei que já era outra época, já era outro tempo; e evidentemente mantivemos que o diretor tinha que ser alguém com doutorado na área de Educação Física ou qualquer outra área. Mas saía o médico, e entrava o doutor, quer dizer, passou a ser a exigência de, como é até hoje, que o coordenador do LAPEX tenha doutorado. Eu acho que é assim, mas nos últimos tempos não tenho controlado. Então eu saí do LAPEX quando fui para o meu doutorado, porque achei que já tinha esgotado a minha margem de passar informação; e a Universidade passou a viver realmente uma época em que tu tinhas que ter titulação acadêmica. Então saí em 1980, e foi aí que terminei minha atividade no LAPEX. O LAPEX teve ainda para mim uma grande contribuição no ensino da ESEF, isto é, todos os professores de ponta hoje da ESEF saíram do LAPEX e foram os primeiros doutores da Escola; porque eu, ainda no meu 
tempo, consegui um projeto para eles irem fazer mestrado em Illinois (EUA). Foram 30 brasileiros para lá, não projeto meu, do LAPEX, mas projeto meu junto à SEED, e nesse eu coloquei quatro professores daqui para fazer esse mestrado, e outros continuaram depois um doutorado. Foram o Fortuna, o Ricardo, o Guimarães... é, acho que foram três. Evidentemente, vamos dizer assim, para mim passou a revolução; então dizer agora o que o LAPEX fez em 1970 é uma coisa normal de se fazer. Tanto que agora está chegando um novo LAPEX que é exatamente o que nós fazíamos antes, com um pouco de diferença na tecnologia; mas a grande função dele foi primeiro mudar o perfil de ensino na ESEF, que era um ensino clássico de Educação Física que vinha com professores de 40, 50 anos, 60 anos sempre ensinando a mesma coisa sem nenhum tipo de atualização. $\mathrm{E}$ esse grupo novo é um grupo com mestrado, doutorado com outra visão de ciência e de atualização, o que obrigou até a própria Escola a se adaptar; porque, no momento em que tu crias um grupo desses, ou tu vais passar a ser como eles, ou tu estás fora. Então hoje se vê que no meu tempo não tinha nenhum doutor; eram dois doutores no máximo quando eu entrei na direção da Escola, isso é uma outra etapa; mas eu tinha cinco doutores, e quando eu saí eu tinha vinte. Então para mim o LAPEX foi um salto de qualidade; os doutores da Escola foram um segundo salto de qualidade; e agora nós estamos num terceiro salto de qualidade, que é a parte instrumental, edifícios, estruturas e outras coisas consolidando todo esse movimento. Que mais que eu posso te falar? Não, eu acho que eu já te falei de tudo, não é? Ainda, talvez, que no LAPEX nós fizemos o primeiro curso de Especialização em Ciência do Esporte, que foi no ano de 1976 dentro do LAPEX. Esse curso foi construído no LAPEX e depois foi albergado fora do LAPEX, nas Ciências Médicas na Faculdade Católica de Medicina; e voltou em 1980 para a Faculdade de Medicina da UFRGS; depois veio em 1985, quando eu voltei do meu doutorado. O diretor da Escola da época pediu que eu trouxesse o curso para cá; e, especialmente nesse período entre 1980 e 1990, nós preparamos aqui mais de 400 profissionais nessa área, a maioria de todos os países da Améri- ca Latina, América Central, Caribe, Hispânico, Europa; então realmente a Escola ficou marcada como uma vocação institucional muito forte na preparação de Medicina do Esporte e Ciência do Esporte. A maioria dos treinamentos práticos deles era feita no LAPEX. Então eu acho que com isso eu te faço um primeiro resumo, agora depois vocês fazem um polimento e tal, e vamos ver o que faltou. O LAPEX teve um regimento que foi feito pela Escola; foi aprovado pelo Departamento, pela Congregação, naquela época, pela V Câmara; e então o diretor era escolhido dentro do regimento. $\mathrm{O}$ regimento tinha esse detalhezinho aí que eu estou te colocando que realmente não tinha muita flexibilidade; mas nem havia interesse, nem disputa política: a grande disputa política com a Escola era uma disputa muito clara entre o fato de que a Escola não tinha nada e o LAPEX tinha tudo. Mas eu sempre trabalhei muito junto da Escola e de todas as coisas que ela tem, por exemplo: todo o sistema telefônico da Escola saiu do LAPEX; também o LAPEX montou a biblioteca. O LAPEX, apesar de ser LAPEX, sempre houve um entrosamento muito grande: a própria sala do diretor da Escola foi feita com recursos do LAPEX; o LAPEX dava material para a Escola. Nós fazíamos uma política de boa vizinhança, mas não deixávamos a direção tomar conta do LAPEX; porque, evidentemente, o LAPEX tinha uma destinação de recursos específica que tinha uma função que era preparar uma nova forma de ver ciência na Educação Física brasileira, não é? $\mathrm{O}$ diretor da Escola tem a necessidade premente de educação, de ensino: ele precisa de mesa, papel... e se ele pega aquele recurso, ele "torra" todo ele -"torra" não: ele até usa muito bem; mas não era a destinação específica do recurso. E então o mecanismo de proteção que nós criamos era para ter as duas coisas: para ajudar um pouco a Escola; mas para poder desenvolver esse novo perfil de professor de Educação Física que é hoje o perfil da Escola.

P - Outro entrevistado fez a seguinte comparação: que o LAPEX era a Bélgica e a ESEF era a índia. Eu queria saber que lugar o LAPEX ocupou na vida da Escola naquela época. 
$\mathrm{R}$ - Isso aí! Eu sempre tive muito problema e tenho até hoje, tanto que o curso de Medicina do Esporte foi proibido de ser feito na Escola; mas nós temos que entender as coisas da seguinte maneira: o LAPEX é um projeto que não foi dado à Escola; foi conseguido por mim. Isso é muito importante para que se entenda como é que o LAPEX nasceu e como é que ele funciona. Uma coisa é alguém chegar na Escola e dizer assim: "Aqui estão 1 milhão e meio de dólares: façam vocês o que quiserem." Outra coisa é como qualquer outro professor deve fazer hoje, num sistema que não existe dinheiro nas instituições federais: saber buscar financiamento fora e saber utilizar. Como tu estás fazendo: tu estás buscando o teu Centro no INDESP, estás procurando a FAPERGS... Se tu vais esperar que o Guimarães te dê dinheiro para fazer isso, tu não vais fazer nunca -eu não quero falar do Guimarães. Então a habilidade de um professor no sistema federal tem que ser a captação de dinheiro. Então quando tu captas -em parte tu és um pouco atrapalhado, mas tu consegues captaraí na hora que tu captas, 30 "caras" querem administrar o que tu captas. Esse que é o princípio seguinte: nós temos que respeitar os professores que captam os recursos, não é? Então nós... Não é que eu queira dizer isso, não é não; eu quero dizer o seguinte: nós temos que respeitar os professores que captam os recursos, então não podemos administrar o recurso do outro; ele tem que administrar o seu. Então a Escola não tem... Tu não podes comparar a Bélgica com a índia, que me dá a impressão, assim, de que eu estou tirando dinheiro da Escola, quando era exatamente o contrário: a Escola não tinha dinheiro, como ninguém na Universidade tinha. Mas a Escola tinha 50 professores como eu, e os outros 49 tinham a mesma obrigação do que eu: buscar os recursos públicos federais e investir na Escola. Então o sistema de manutenção era um sistema de proteção até da Universidade, porque o reitor, quando vinham as conclusões, sempre dizia: "Mas o De Rose... Deixa o De Rose: ele é o único que traz dinheiro. Todo mundo me pede, e ele me traz. Vou deixar ele lá até ele parar de trazer." Então o LAPEX -claro que temos que entender a pessoa humana- ele motivou ciúme, mo- tivou problemas; mas tudo isso é coisa normal da vida, entende? Até hoje eu te diria que existem duas classes de professores na Escola; e a Escola continua pobre, e o LAPEX continua rico: não tem diferença da época.

$\mathrm{P}$ - Quanto à procedência dos recursos financeiros?

R - Eram recursos do Governo Federal, do Ministério de Educação, alocados pela Divisão de Educação Física e Desportos do MEC.

$\mathrm{P}$ - Tu podes me precisar até que época vocês receberam esses recursos? Por que hoje o LAPEX não tem mais esses recursos?

$\mathrm{R}$ - Até a época em que eu fiquei na direção do LAPEX: foi de 1971 até outubro de 1988.

$\mathrm{P}$ - Quais os principais problemas que vocês enfrentaram na época da implantação do Laboratório?

$\mathrm{R}$ - Eu te diria que o maior foi... não chegou a ser um problema, a maior dificuldade foi negociar com a ESEF um trânsito, entende? Porque isso não era só comigo: era com todo o pessoal da ESEF. Imagina um professor que dá aulas há 30 anos aqui nunca ter saído para São Leopoldo; aí vem um guri como o Guimarães, e eu mando ele para os Estados Unidos fazer biomecânica. E claro que havia um choque nessas coisas, mas eu acho que o maior problema foi exatamente essa diferença de um projeto com muito dinheiro para uma Escola com pouco dinheiro. Mas em momento algum isso chegou a impedir: houve momentos mais fáceis, momentos mais difíceis, mas nunca houve um bloqueio; até porque o projeto era totalmente independente.

P - Qual é o papel do LAPEX hoje na ESEF, depois de passados quase 25 anos?

$\mathrm{R}$ - Eu vejo que hoje o perfil é diferente, quer dizer, não há tanta necessidade como havia naquela época. O perfil dos professores na Escola é muito diferente do meu tempo, embo- 
ra eu ainda esteja no meu tempo; mas, enfim, eu vejo que o LAPEX de ontem ajudou o LAPEX de hoje, entende? Quando o Ministério de Educação e Cultura através do INDESP buscou um centro de referência, ele se baseou numa tradição; ele se baseou numa história mais do que numa realidade. Não sei se está perfeito. O LAPEX hoje é conhecido no mundo, em qualquer um dos 120 países que fazem Ciências do Esporte; e se tu disseres que és de Porto Alegre, eles vão te dizer duas palavras: a primeira é LAPEX -veja que coisa impressionante. Então isso tem uma história.

P - Um dado que chamou minha atenção nos relatórios é a presença de um grande número de espanhóis estagiando e pesquisando no LAPEX. Como eles vieram para o Laboratório?

R - É dos estrangeiros, não é? Foi o que eu te falei sobre o curso que nós começamos em 1976. Primeiro nós começamos com estágio. Esse curso começou como estágio em 1975; porque, como o LAPEX era conhecido em toda América Latina, as pessoas começaram a pedir para fazer estágio aqui. Então começou o primeiro estágio em 1975. Era estágio; então vinha um menino e fazia um estágio conosco um ano, aprendia nossas técnicas e ia embora. Foi quando começou a haver muitos pedidos de estágio que eu resolvi criar o curso, que foi em 1976. De 1976 em diante, o estágio se formalizou num curso de pós-graduação em nível de especialização; e os médicos e os professores de fora, que não eram daqui, como ficavam "full time" aqui, eles tinham as aulas, e quando não tinham aulas, trabalhavam como monitores no LAPEX. O LAPEX tinha toda uma área de avaliação que era muito ativa: nós trabalhávamos com todos os atletas de Porto Alegre, do Rio Grande do Sul e do Brasil; e toda a área de sedentários nós começamos a avaliar para a prescrição de exercícios. Isso tinha sempre, pois era como um serviço aberto. Então, como não tínhamos mão-de-obra, porque não tínhamos com quem trabalhar, o monitor era a nossa mão-de-obra: ele aprendia e nos ajudava. Daí então tu vês naqueles relatórios do período do Jorge aquela lista de monitores.
P - Então o LAPEX começou a ter um padrão internacional?

$\mathrm{R}$ - Para tu teres uma idéia do padrão do LAPEX, em 1975 nós fomos convidados para fazer os projetos de ciência dos jogos pan-americanos do México. Então fomos com o grupo para lá todo uniformizado e fizemos várias análises: eu, por exemplo, trabalhei na análise cineantropométrica dos lançadores de peso; e houve vários outros projetos. Então nós íamos num grupo de seis, sete e voltávamos sempre fazendo os projetos: o nosso trabalho era muito desse tipo. Também começamos a dar apoio ao Ministério da Educação no treinamento de outros países; então o LAPEX foi para o Equador, para a Bolívia, Argentina, Uruguai, Paraguai, Colômbia montando pequenos LAPEX através de programas do Governo Brasileiro e treinando o pessoal de lá. Então ele sempre teve a conotação tipo acadêmica. Ele começou a ter com o Jorge depois, porque aí já não havia mais o projeto: aí já era um serviço que não tinha mais o recurso que tínhamos naquela época, então ele mudou para um projeto um pouco mais acadêmico.

P - Naquela época da criação do LAPEX, o Governo Brasileiro estava com o chamado Projeto Brasil, acredito que no mesmo período da campanha do Esporte para Todos. Os laboratórios de pesquisa, como o LAPEX, também vieram na perspectiva desse projeto?

$\mathrm{R}$ - Eu já tive, numa ocasião em um congresso em Portugal, a possibilidade de discutir, porque eu estava de presidente de uma mesa, com um brasileiro do Rio de Janeiro que apresentou uma idéia de que os laboratórios criados na época dos militares eram feitos para que se sustentasse uma filosofia militar, de apoio à revolução, ao Governo da ditadura. Não sei o que tu queres dizer com isso; quero te dizer o seguinte: eu nunca na minha vida, como coordenador que fui de todo esse período, recebi uma ordem, uma informação, uma definição, uma decisão ou uma orientação de que eu deveria estudar a, b, c ou d. Eu... Nós aqui em Porto Alegre -eu tenho que me limitar ao que eu era, não sei o que os outros eram- mas eu 
nunca tive nenhuma influência ou inserção do sistema para dizer o que eu estudava: o que eu estudava era o que eu achava que devíamos estudar como grupo. Nós nos reuníamos e éramos limitados, porque éramos autodidatas. Nós saíamos para pesquisar: o Jorge foi treinar fisiologia do esforço com o Otrio na Suécia; o Benno foi para a Itália treinar Psicologia com o Antonelli. Nós buscávamos os melhores professores do mundo, os melhores centros do mundo: as nossas pessoas iam para lá, estagiavam e voltavam para aplicar aqui. Eu nunca tive esse tipo de coisa que eu vejo, por exemplo, alguns autores brasileiros da área de mais de esquerda comentarem; realmente nunca tive esse problema.

P - Então qual era o retorno que o Laboratório tinha que dar para o Governo?

$\mathrm{R}$ - Nós tínhamos de dar um retorno que, vamos dizer... não um retorno. Qual era a nossa função, qual era a função do projeto? A função do projeto era transferência de tecnologia, quer dizer, numa área que não havia nenhuma tecnologia, como é que se avalia um atleta; como é que se prescreve um treinamento; como é que se faz ciência do esporte. A tecnologia era zero, então a nossa função era transferência de tecnologia; era criar centros no Brasil e profissionais brasileiros capazes de apoiar o esporte de alto rendimento, que era a prioridade do Governo. Agora, parte da nossa habilidade aqui no Rio Grande do Sul foi que, apesar de não deixarmos de trabalhar no esporte de alto rendimento, por uma questão de formação, nós sempre nos preocupamos com saúde de massa; e toda a nossa linha, se tu observares a produção científica, sempre teve a preocupação paralela de criar. O que nós fazemos com o atleta, por exemplo, eletrocardiografia de esforço e esteira, também era propiciado ao sedentário fazer atividade física. Então, para te dar uma idéia, todas as clínicas de reabilitação de cardíacos saíram do LAPEX: a Physis, a Prevencor e a Cardioclínica, as três se originaram no LAPEX de tecnologia desenvolvida no LAPEX direcionada à prevenção e ao tratamento de populações isquêmicas, que é um projeto sedentário que não tem nada que ver com o projeto de alto rendimento. Então nós tínhamos a total liberdade de poder trabalhar nas duas áreas; embora evidentemente, que a idéia, até porque vem do Departamento de Educação Física e Desportos e não vem do Ministério de Saúde, era de promover o maior conhecimento em*todas as áreas do esporte: esporte de alto rendimento, esporte comunitário, esporte escolar. Nós trabalhávamos muito o esporte escolar, que era organizado pelo DED, e esporte amador; então trabalhávamos nas duas áreas.

P - Existe uma relação entre o projeto de criação dos laboratórios daquela época com o que o INDESP propõe hoje com a implantação dos Centros de Excelência Esportiva?

$\mathrm{R}$ - Acho que é a mesma coisa: detecção de talentos e esporte de rendimento. É a mesma coisa, até porque todo mundo que está no INDESP era do INDESP no meu tempo, era da sede MEC e depois era do DED; então não tem muita diferença.

\section{Entrevistado: médico Belmar José Ferreira de \\ Andrade}

Data de Nascimento: 25/1 2/1 945 Entrevistadora: Profa. Janice Zarpellon Mazo Data da Entrevista: 23/04/1 997 Transcritor: Luciano do Amaral, acadêmico do curso de Licenciatura em Educação Física da UFRGS

\section{P - Quando entraste para o LAPEX?}

$\mathrm{R}$ - Bom, eu ingressei aqui no LAPEX em... 1972, eu imagino. De vez em quando eu já me perco um pouquinho nas datas, mas imagino que tenha sido em 72 .

\section{P - Como foi o teu ingresso?}

$\mathrm{R}$ - A coisa foi mais ou menos assim: eu fui convidado pelo De Rose quando ainda estava nas tratativas de início do LAPEX, por causa da minha formação em cardiologia, em medicina desportiva; trabalhava com esporte; tinha sido atleta; e tudo isso. O De Rose já me 


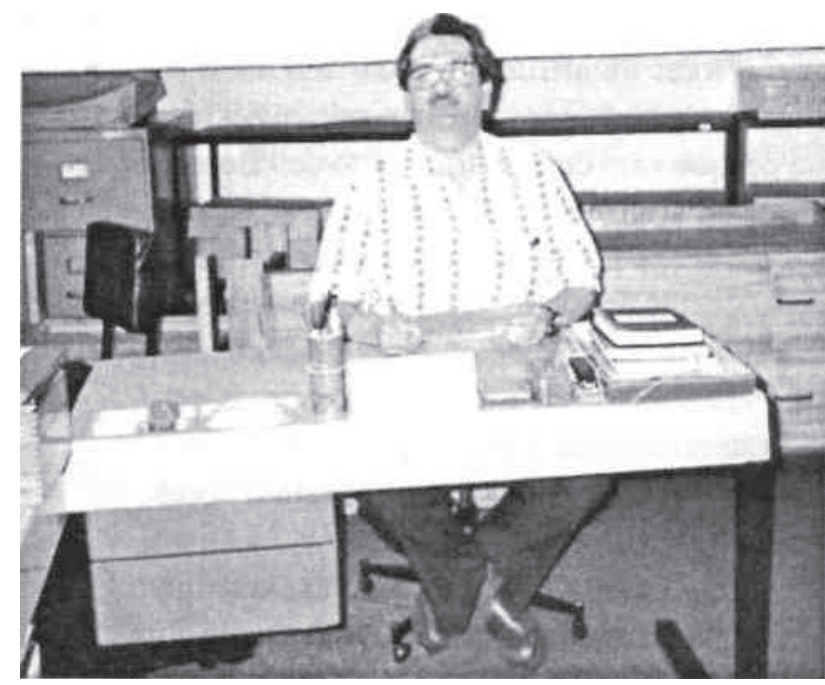

Belmar José Ferreira de Andrade é Médico graduado pela Faculdade Católica de Medicina de Porto Alegre em 1969. Especialista em Medicina Desportiva pela ESEF/UFRGS. Residência médica no Instituto de Cardiologia de Porto Alegre. Foi coordenador do LAPEX no periodo de 1980 a 1986. Atualmente, é médico no LAPEX.

conhecia do trabalho em outros clubes: no Grêmio, onde ele era médico; no Grêmio Náutico União, quando tínhamos trabalhado juntos em alguns exames de piscina, essas coisas com atletas. Então ele me convidou para fazer parte dessa equipe que ia tocar esse Laboratório que estava para acontecer aqui, dentro de um projeto do Governo que ia instalar alguns laboratórios no Brasil, etc. Então ele me convidou para vir para cá; eu vim para cá; e, dentro dessa proposta, apareceu a proposta de um curso de monitores de pesquisa em Educação Física e Desporto, que ia acontecer no Rio de Janeiro, na UFRJ, no fundão, na Escola de Educação Física. Nessa época, eu e mais alguns professores e alguns médicos -acho que o mais antigo era o Eron Beresfor, que era responsável pelo Ginásio de Esportes da Brigada Militar, que era bem recente, tinha sido inaugurado para a Universíade 10 anos antes- e o Eron Beresfor era um professor já formado. E seus alunos daqui da ESEF que eram interessados no assunto, entre esses que nós encontramos aqui estavam o atual diretor da ESEF, o Guimarães; o ex-diretor da ESEF, o Ricardo Petersen; o Adroaldo Gaya, que é professor da Escola. Tínhamos mais dois professores de
Educação Física que não ficaram na Escola: o Hélio Becker, que era um professor que trabalhava em Novo Hamburgo, tem uma escola de natação lá, tinha sido campeão brasileiro de natação; o Schroeder, que eu não me lembro do primeiro nome, era um aluno dele. E tinham alguns estudantes de medicina também, entre eles estava o Caco; o João Ricardo Magni, atual presidente da Federação Brasileira de Medicina Esportiva; o Mário Aurélio, que depois saiu daqui, depois que se formou, foi fazer sua clínica em Florianópolis; o Sindal, que é outro médico, deve estar em Porto Alegre, e que foi para lá. Então eu acredito que esse seja o grupo, talvez um ou outro que eu não tenha lembrado no momento, não é? Mas esse grupo que foi para o Rio de Janeiro fez esse curso de Monitores de Educação Física e Desporto e de Pesquisa para começar as atividades do LAPEX. Então nós voltamos para cá, começamos a montar, ao longo de 73 , as baterias de exames para avaliar escolares, para avaliar atletas; colocar em funcionamento as máquinas novas que iam chegando; testar essas máquinas na nossa população; revalidar para a nossa população dados que nós tínhamos de literatura de outros lugares; etc. Me lembro de que nessa época existia um tal de Projeto Brasil, que era um projeto que tentava dar a dimensão da capacidade física, digamos assim, da aptidão física do brasileiro. Esses dados eram correlacionados com dados de outros lugares; e, ao longo desse início, vieram para cá muitos professores para dar cursos aqui. Logo no começo, houve um curso dado aqui pelo doutor professor Bruno Bauth, era um alemão que trabalhava nos Estados Unidos e que passou bastante tempo aqui nos dando curso sobre fisiologia do exercício -ele é um dos papas da fisiologia do exercício no mundo- eu acho que até umas duas semanas dando um curso. E assim como ele vieram outros professores de fora, gente renomada que veio dar curso de formação para o pessoal daqui. Nós começamos a trabalhar, fizemos trabalho com equipes, com federações, com seleções ao longo dos anos; e aí o pessoal daqui começou a sentir a necessidade de fazer formação fora, e aos poucos o pessoal foi saindo, foi fazendo a sua formação no exterior. Eu, em função de minha atividade 
numa série de empregos, estava preso aqui. Tive uma oportunidade de sair em 1975, quando fui para Colônia, na Alemanha, e acabei fazendo um curso lá, mas foi um curso de pouca duração, não lembro, deve ter sido pouco mais de um mês, coisa desse tipo. Eu fui junto com um outro colega daqui do Rio Grande do Sul, o Algayer; e dois colegas, um de São Paulo e um do Rio de Janeiro: a Maria Augusta Kiss, de São Paulo; e o... me fugiu o nome agora, o... ele era diretor da Escola de Educação Física, daquela Faculdade Castelo Branco do Rio de Janeiro... José Rizzo Pinto. Então fizemos esse curso na Alemanha juntos, os quatro, e passamos esse período lá. curso?

P - Não eram só médicos, então, nesse

R - Eram todos médicos, e ele era diretor da Escola de Educação Física, mas era traumatologista. A Maria Augusta é fisiologista, e o Cláudio Algayer é da área de Administração. Ele foi para lá mais interessado na área de documentação e informação, biblioteca, foi para essa área aí; e depois voltamos e continuamos a trabalhar aqui até hoje.

P - Como eram as instalações no começo do Laboratório?

$\mathrm{R}$ - As instalações não eram exatamente como aqui onde nós estamos neste momento, mas era no andar de baixo. Aqui onde nós estamos, naquela época era a sala de judô da Escola; aqui eram as aulas de judô, exatamente neste local onde nós estamos. Onde está sendo montado o laboratório de biomecânica, ali era que funcionavam todas as instalações do LAPEX, naquela área ali embaixo do andar térreo. Era do lado do Diretório Acadêmico da Escola; do bar da Escola, que era aqui neste canto. Então foi aqui que começou tudo; depois fomos ganhando este espaço aqui dentro, ao longo do tempo; e hoje, se Deus quiser, teremos um prédio novo, independente, que está projetado já há bastante tempo.

P - Como era o tipo de pesquisa que vocês faziam na época?
$\mathrm{R}$ - Digamos assim que, na realidade, muita coisa que nós temos hoje como dogma dessa área era tudo novo. Faz vinte e tantos anos, 25 anos praticamente; então, assim, a fisiologia do exercício, o treinamento físico como uma especialidade definida eram coisas muito novas: isso tudo não existia no currículo das faculdades nem de Educação Física, nem de Medicina. Era uma coisa nova, e nós estávamos "pescando" tudo que estava ocorrendo no mundo e repetindo aqui: era uma pesquisa de confirmar dados de pesquisa de outros centros, de confirmar resultados de outras populações, ver se eles se reproduziam na nossa população, treinar tecnologia e treinar técnica, não é? Repetir para comparar os resultados com os outros. Então era mais nesse sentido o tipo de pesquisa.

$\mathrm{P}$ - O que avançou na pesquisa do Laboratório passados 25 anos?

$\mathrm{R}$ - Eu tenho a impressão de que o que avançou mais, na realidade, assim me atendo mais na minha área, a cardiologia, naquela época nós tínhamos assim... Então começamos a investigar aqui o eletrocardiograma do atleta, o coração do atleta; questões referentes ao treinamento com indivíduos sadios; do coração, da pressão, com indivíduos cardíacos; essas respostas ao exercício; tudo isso foi sendo reproduzido aqui, testado, verificado; e hoje isso é uma coisa segmentada. Naquela época era tudo uma novidade e uma coisa muito nova até mesmo para Brasil, não só para Porto Alegre, mas para Brasil. Na verdade, aqui chegaram coisas antes mesmo que em qualquer outro ponto do Brasil; então, ao longo desse tempo, como nós estávamos aplicando esses conhecimentos aqui, detendo em relação à parcela mais apreciada desse conhecimento, começamos a exportar isso para o resto do Brasil e da América Latina. Era extremamente freqüente que nós viajássemos para dar cursos na Argentina, no Uruguai, no Chile, no Equador, na Bolívia, no Paraguai, na Colômbia, no Peru. Em tudo isso, nós vivíamos viajando e transferindo esse conhecimento novo que nós tínhamos, digamos assim. Do ponto de vista da pesquisa pura de descobrir coisas novas, na realidade eu acho 
que até hoje nós não tivemos pesquisa de peso, de ponta, entendeu? Mas conseguimos, assim, a um longo tempo, transferir esse conhecimento do circuito fechado da pesquisa pura para o circuito da aplicação quotidiana desses conhecimentos. Na realidade, eu acho que este é o principal papel do LAPEX: ele foi uma interface que tirou do circuito fechado dos pesquisadores e repassou isso para a comunidade em geral. Acredito que o papel de disseminação desse conhecimento foi muito grande. Então se publicou muita coisa que nós olhamos hoje e sentimos até vergonha de termos publicado algumas aí, mas naquela época era válido.

P - Desde que o LAPEX foi criado, na década de 70, os médicos sempre estiveram na coordenação. Por quê?

$\mathrm{R}$ - Eu tenho uma idéia bem clara disso, e isso aí repete no LAPEX o que aconteceu na Escola de Educação Física: a Escola teve inúmeros médicos como diretores até que tivesse o corpo de professores de Educação Física; porque a Medicina se desenvolveu antes da Educação Física, como uma ciência bem estruturada e com profissionais que procuravam se inteirar com a pesquisa. Então é o que aconteceu com a Escola de Educação Física, que teve uma série de médicos como diretores até que os professores assumissem; e se repetiu no LAPEX, porque uma série de médicos assumiu até que os professores assumiram isso; porque o curso de Medicina dá uma formação bem melhor do que o curso de Educação Física. É muito recente, por exemplo, o conhecimento sobre fisiologia nos cursos de Educação Física, que não era antigamente e que já era recentemente mais valorizado nas escolas médicas. O conhecimento da coisa é que vai dar muitas outras situações! Está assim: um indivíduo sadio... ele começa com um indivíduo doente, então quando falta solução, se descobrem e se identificam os mecanismos fisiológicos que sirvam naquele tipo de repulsão. Achamos muita coisa em comum em várias áreas do conhecimento, em que o paralógico é que gera a pesquisa e gera o conhecimento, que nos trás à luz do mundo, da normalidade: é mais ou menos um paralelo com todo o nosso avan- ço tecnológico, mais ou menos um subproduto. O nosso bem-estar é um subproduto da pesquisa bélica, todo o avanço tecnológico tem uma função eminentemente para a guerra, e não existe nenhuma exceção nisso. Toda pesquisa é para propósitos de guerra e, depois de certo tempo, ela é estendida, digamos assim, para o nosso cotidiano e gera uma série de avanços de bemestar para a população. Mais ou menos isso acontece aqui com o ser humano: nós pesquisamos os doentes, os enfermos, os incapacitados, e com isso descobrimos uma série de coisas que trazem à luz melhorias; e talvez por isso os médicos tenham sido os indutores primários do processo e depois foram sendo absorvidos. Eu acho que isso é um paralelismo que fica muito bem.

P - Por que o Laboratório foi instalado na Escola de Educação Física e não na Faculdade de Medicina?

$\mathrm{R}$ - Existe uma tradição de esses laboratórios estarem localizados nas Escolas de Educação Física; existe hoje uma tendência. Quem sabe isso aí teria sido "melhor aproveitado", digamos assim, se tivesse sido instalado numa Escola de Medicina? Mas eu tenho a impressão de que a sensibilização do médico para essas coisas teria sido muito menor, e aí teria sido um avanço muito pequeno. Então hoje é difícil dizer se teria sido melhor localizado na Escola de Medicina do que na de Educação Física. Não sei, estou em dúvida. A respeito dos laboratórios estarem em várias capitais do Brasil, que me represente, os laboratórios primariamente eram quatro, no projeto do Governo: eram em Brasília, Rio, São Paulo e Porto Alegre. E que esses laboratórios recebessem um aporte mais maciço de verbas, de suporte, e se desenvolveria a tecnologia "de ponta" para a época. Nas demais universidades federais localizadas nas outras capitais e nas principais cidades -como Santa Maria, Pelotas- seriam desenvolvidos laboratórios de um segundo escalão e que, no Brasil inteiro, ficariam na dependência ou subordinados a esses quatro laboratórios, que dariam a formação inclusive do pessoal. Isso chegou a ser esboçado, e houve algumas ações concretas. Eu me lembro, por exemplo, que nós 
vimos, assim, uma das ações era que o laboratório de Natal, no Rio Grande do Norte, ficaria sob a jurisdição do laboratório de Porto Alegre; assim como o de Pernambuco, em algumas outras cidades da Bahia. Não foi nem uma nem duas vezes que o pessoal daqui foi para lá, promoveu cursos, formação de gente; e de todos esses lugares vinha gente fazer estágio aqui, ser treinado aqui. Isso é mais ou menos o que ficou claro para mim ao longo de alguns anos de funcionamento do LAPEX. Eu não sei... Eu desconheço os detalhes escritos dessas coisas, mas é mais ou menos o que ficou claro para mim, da política que orientava nessa época.

\section{P - Como era a relação do LAPEX com} a Escola?

$\mathrm{R}$ - A interação do LAPEX com a Escola teve, ao meu entender, altos e baixos. $\mathrm{O}$ LAPEX começou vinculado fundamentalmente com a pesquisa, e a pesquisa não era uma pesquisa de ponta: era uma pesquisa eminentemente aplicada e reprodutiva do que já existia -validação de técnicas, de dados, objetos populacionais. E nasceu, digamos assim, voltado mais para performance, para estudar fundamentalmente o atleta e o escolar. Ele serviu de base para os cursos de pós-graduação da Escola, que naquela época eram cursos de especialização, de extensão mesmo, e depois foram aumentando; eram cursos depois destinados a médicos. Havia um curso de Medicina Esportiva na Escola que funcionava aqui. Isso foi trazendo gente de fora, mais por ação direta do De Rose, que viajava muito, divulgava muito o nome do LAPEX; então começou a vir muita gente de fora, fundamentalmente médicos da América Latina toda e muita gente aqui dentro. O LAPEX servia de base para o exercício prático dos cursos; então, além das pesquisas, todo ele foi um suporte desses cursos de pósgraduação e especialização em Medicina Esportiva, Treinamento Desportivo, etc. Esses vários cursos da Escola eram o que acontecia ao longo desse tempo. Na graduação ele teve, assim, pouca influência; até mesmo porque na graduação não era dada tanta ênfase nas coisas que hoje são realizadas no LAPEX. Havia disciplinas, que eu acredito que até hoje são optativas, não são obrigatórias no curso, como fisiologia do exercício, avaliação funcional, e talvez outras aí que não eram disciplinas obrigatórias da graduação. Então vinha para cá o aluno interessado; mas não vinham obrigatoriamente nem compulsoriamente todos os alunos da Escola; e eu acredito que até hoje seja assim: a graduação aproveita menos o LAPEX do que a pós-graduação lato sensu, não é? A extensão, a especialização, aperfeiçoamento, o mestrado, doutorado não tem... são os que mais aproveitam o LAPEX. Digamos assim que o LAPEX começou com o forte -a pesquisa, o instrumental e o pessoal- dirigido fundamentalmente para a análise fisiológica da performance e do treinamento: então estudo do metabolismo -aláctico, aeróbio, anaeróbio, láctico, etc; da antropometria; da cineantropometria, que nós tivemos vários profissionais de fora daqui estudando o perfil da forma humana e das proporções. E isso foi muito destacado, mas paulatinamente com os profissionais diminuindo nessas áreas e tendo formação; e aí entram mais as áreas de aprendizagem motora, de biomecânica, cinesiologia aplicada, etc. que, no meu entender, são a parte mais forte do atual LAPEX. Hoje o LAPEX é muito mais dirigido para isso, a tecnologia foi deslocada para esse tipo de pesquisa, os profissionais formados que hoje estão aqui... Isso é uma área mais da Educação Física do que da Medicina. Então eles foram mudando o horizonte do LAPEX. Permanece aqui ainda a área de metabolismo, que é uma área fundamental para a avaliação funcional, para treinamento físico. Então permanece ainda um médico aqui dentro como eu, porque existe uma série de coisas que ainda precisam de médico aqui dentro, quer dizer: o exame clínico, o exame de aptidão para a prática desportiva, a idoneidade de saúde do indivíduo para a prática ou não, alguns procedimentos são feitos aqui. Existe, assim, um requisito que é um médico presente. O Crescente ainda trabalha aqui, se bem que não regularmente, também nessa área. Então se mantém esse serviço de ergonometria, que é tradicional aqui, avaliar o indivíduo para o programa da Escola, não é? -esses programas de hidroginástica, de jogging, de condicionamento físico, de musculação, esses vários progra- 
mas da Escola- e existe aqui para apresentar uma sanidade física. Então nós continuamos vindo para cá; o pessoal continua a oferecer essa avaliação aqui, que fundamentalmente é uma avaliação rotineira, mas para haver condições de saúde: se o eletrocardiograma é normal, se a pressão é normal, se a pessoa tem ou não tem alguma contra-indicação formal para a prática desses programas. Além disso, a parte mais funcional, propriamente dita, está sendo desenvolvida em paralelo hoje pela Flávia, que é outra médica, outra professora da Escola que está desenvolvendo isso com o Cláudio Paiva e com outros funcionários- aí que é uma avaliação mais dirigida para o atleta propriamente dito. Mas eu tenho a impressão de que isso ainda é pouco requisitado; o exame de sanidade ainda é um exame que caiu mais no gosto "por conta do freguês" do que esses outros parâmetros. As coisas foram mudando paulatinamente: quando nós fazíamos a avaliação inicialmente, os treinadores não aproveitavam o resultado do teste que eles faziam porque desconheciam totalmente esse assunto; hoje os treinadores formados na Escola tiveram conhecimento disso, por literatura ou noutro lugar, já vêm aqui procurar respostas para essas questões e eles têm do ponto de vista de treinamento, avaliação, etc. Houve uma modificação do perfil: o conhecimento intrínseco e amplo das

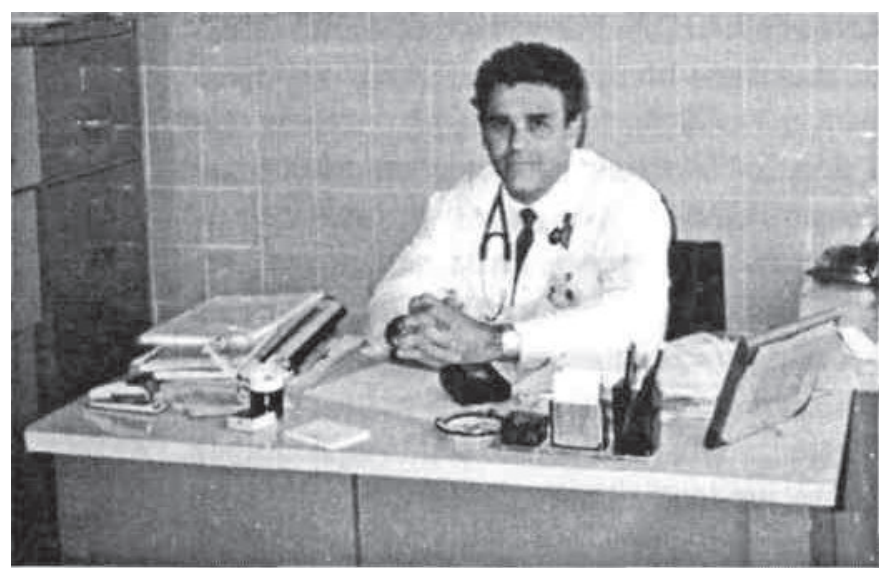

Jorge PINTo RIBeIro é Médico graduado pela UFRGS em 1978. Especialista em Medicina do Esporte pela ESEF/UFRGS em 1979. Especialista em cardiologia pela Universidade de Ilarvad (EUA). Doutor em Fisiologia do Exercício pela Universidade de Boston (EUA). Foi coordenador do LAPEX no periodo de 1986 a 1990. Atualmente é professor do Curso de Medicina da UFRGS. coisas ainda é muito semelhante ao inicial. O que houve foi uma disseminação desse conhecimento, uma burilação desses conhecimentos e que hoje já segmentaram muito mais e terminaram com alguns tabus, colocaram no devido lugar algumas avaliações, prepulsões. É isso.

\section{Entrevistado: médico Jorge Pinto Ribeiro}

Data de nascimento: 09/04/1 955 Entrevistadora: Profa.

Janice Zarpellon Mazo Data da entrevista: 1 2/08/1 997

Transcritor: Luciano do Amaral, acadêmico do curso de

Licenciatura em Educação Física da UFRGS

P - Fale sobre sua formação acadêmica.

R - A minha formação acadêmica se confunde até com a minha relação com o LAPEX, porque eu comecei a minha atividade de iniciação científica quando eu estava no terceiro ano da Faculdade de Medicina e comecei a fazer um estágio; seria o equivalente do que hoje em dia se chama iniciação científica. Então eu comecei no segundo semestre de 1975 e trabalhando. Naquela época fui encaminhado pelo professor Jayme Werner dos Reis, que me conhecia. Eu tinha um interesse em esporte pelo fato de eu também ter sido atleta; então o professor Jayme Werner, sabendo que eu era nadador -foi meu professor de Educação Física quando eu era aluno do Colégio de Aplicaçãome recomendou entrar em contato na época com o coordenador do LAPEX, que era o professor De Rose; e eu me apresentei para fazer um programa de iniciação científica, não é? Então, ao longo de toda a minha graduação, a partir do final do terceiro ano e os outros anos na graduação de Medicina, eu trabalhei no LAPEX como aluno de iniciação científica, vamos dizer assim -naquela época não existia essa estrutura, mas seria o equivalente hoje em dia. Eu me formei em 1978 na Faculdade de Medicina da UFRGS e comecei um programa de residência médica aqui no Hospital de Clínicas que eu fiz em 78 e 79, desculpa, é fundamentalmente 79,80 e parte de 81 . Nesse período, mesmo sendo residente aqui, eu continuei 
tendo atividades no LAPEX e fiz também, ao longo da residência, o curso de pós-graduação em Medicina do Esporte no ano de 1979, que na época era coordenado pelo professor De Rose. Em 81 eu -através de uma bolsa de estudos do CAPES e encaminhado pelo processo de pós-graduação, ou melhor, da minha atividade na medicina do esporte e na fisiologia do exercício- fui fazer meu programa de doutorado na Universidade de Boston. Nessa mesma época, eu recém tinha sido contratado como professor auxiliar da ESEF, trabalhando no LAPEX, e eu saí para o meu programa de doutorado. Então, em afastamento como professor da ESEF -naquela época nós ainda estávamos no regime militar, e não havia praticamente concursos públicos, então eu não entrei concursado na carreira acadêmica- eu passei de 81 a 85 em Boston, onde fiz doutorado em fisiologia do exercício, que era a atividade que eu desenvolvia naquela época, e fiz também o meu treinamento em cardiologia. Então, ao final de 85, eu voltei para Porto Alegre, voltei para o LAPEX, tendo que terminar meu doutorado em fisiologia do exercício e a residência em medicina interna aqui; e o treinamento também seria o equivalente à residência aqui em cardiologia, que eu fiz na Harvad. Fiz doutorado na Boston University e em cardiologia na Harvard. Então, a partir de 85, eu voltei para o LAPEX para reiniciar minhas atividades. Essa é minha formação acadêmica.

P - Quando retornaste para o LAPEX, em 1985, assumiste a coordenação?

R - Não. Logo que eu cheguei... aí tem um momento muito importante; talvez eu já vá fazendo alguns comentários que são importantes do ponto de vista histórico. O LAPEX, a partir de 73, foi montado dentro de um projeto que vocês já conhecem de um apoio econômico bastante forte resultando na construção da primeira etapa do LAPEX e numa quantidade razoável de equipamentos. Naquela época, o que acontecia é que pouca gente tinha real formação acadêmica nessa área no Brasil; e o doutor De Rose buscou orientação na nossa área aqui, na área de fisiologia do exercício, buscou orientação com o professor Rigato, que ajudou em algumas estratégias de compra de equipamentos. Mas fundamentalmente nenhum de nós tinha formação: eu era estudante de Medicina na época, e vários outros atuais professores eram estudantes de Educação Física ou Medicina. Aquela experiência foi muito rica, na medida em que nós tínhamos equipamento de alta qualidade e também a oportunidade de trânsito internacional que esse convênio propiciava: eu, por exemplo, comecei a trabalhar em final de 75 e já em janeiro de 77 tive a oportunidade de fazer estágio no exterior para visitar laboratórios de pesquisa do exercício na Europa. Ah! Existia uma bolsa da Federação Brasileira de Medicina do Esporte; então eu visitei, ao longo dos meses de férias, janeiro e fevereiro, eu tive a oportunidade de visitar um instituto em Roma; um em Colônia, na Alemanha; um em Estocolmo; e o de Vasquila, na Finlândia. Isso permitiu conhecer o funcionamento desses laboratórios de pesquisa, que eram os melhores da Europa naquela época, e essa experiência me trouxe realmente uma visão de como seria uma estratégia acadêmica. Então essa foi uma primeira etapa; vários de nós do LAPEX fizemos isso: estágios curtos em laboratórios, conhecer como é que as coisas funcionavam. Mas o professor De Rose, nessa época, eu acho que já tinha uma visão bem clara, embora, naquela época, ainda não tivesse feito a sua formação acadêmica. Ele já tinha uma visão bem clara do que era uma trajetória acadêmica e conseguiu fazer um planejamento (até hoje ele ainda continua fazendo!) de investir na formação de recursos humanos. Naquela época, e hoje também, esse investimento era na formação de mestres e doutores; e ele oportunizou para todos, nós através de contato internacional, a possibilidade de fazer pósgraduação no exterior. Então, como eu já relatei, eu tive oportunidade de ir para Boston, porque em Boston eu tinha a oportunidade de desenvolver as minhas duas áreas de interesse, que eram fisiologia do exercício e atividade clínica aplicada ao exercício; e vários outros professores foram também para o exterior e fizeram essa formação. É importante deixar bem claro que não são todos os líderes acadêmicos que dão essa oportunidade que nos foi dada. Nós tivemos essa oportunidade, e alguns de nós 
aproveitamos bastante, então eu acho que essa foi uma etapa muito importante: primeiro, montar o Laboratório, criar um núcleo e começar a implantar algumas técnicas que ainda não existiam em nosso meio; segundo, se dar conta de que a nossa formação não era suficiente e que simplesmente fazer visitas curtas não era suficiente para formar pesquisadores. Então o De Rose incentivou a sair vários de nós; e, no início dos anos 80 , estivemos no exterior fazendo a nossa formação. Infelizmente neste período entre 80 , eu diria entre 81 e 85, o Laboratório, porque nós saímos ao mesmo tempo: saímos eu, o De Rose, o Guimarães, o Ricardo Petersen... quem mais?... o Fortuna -eu acho que são esses- todos saíram ao mesmo tempo, se de um lado um objetivo nobre de outro laboratório, na realidade nesse período caiu muito a produção em todas as atividades que ele desenvolvia. Então, quando nós voltamos, em 85, o Laboratório estava praticamente desativado, e nós começamos a trabalhar: o De Rose com as coisas dele, o Guimarães montou uma área nova, eu montei; e com isso o Laboratório conseguiu retomar uma atividade. E, no ano seguinte, em 86 , fui nomeado coordenador, que depois passaria pela mudança das características do Laboratório para o cargo de diretor. Então o período de 81 a 85 foi um período muito ruim no sentido de que nós tínhamos os recursos humanos que estavam fazendo investimentos em formação; e nesse período vários equipamentos também passaram a... como não eram utilizados, tiveram uma manutenção limitada: houve uma queda importante. Mas a partir de 85 houve um retorno, não é? O De Rose montou uma linha de pesquisa dele, eu montei minha linha de pesquisa, e as coisas começaram a andar novamente.

P - Ao fazer a leitura dos relatórios, observe a presença de estagiários de diferentes países, como, por exemplo, do Equador e da Espanha. Eu gostaria que comentasses a respeito desses estrangeiros no LAPEX.

R - É, a liderança do De Rose, internacional, nos propiciou esse contato $\mathrm{CG} n$ várias pessoas no exterior; e, desde 76, acho que sempre tinha um estagiário pelo menos. Eu imagi- no que ao longo dos anos sempre se teve e em... não sei se em 76, agora eu perco um pouquinho a noção, talvez tenha alguns nomes. Então até 81 nós tínhamos alguns estagiários; e de 81 a 85 , que foi o período em que o De Rose esteve fora, houve uma queda desse número de estagiários, retomando num crescimento vertiginoso, que foi no final dos anos 80 , um número muito grande de estagiários que refletia naquele momento também até a qualidade do nosso programa. Nós tínhamos, já no final dos anos 70 , já existia o curso de pós-graduação em Medicina do Esporte e/ou Ciências do Esporte. Esse haver ou não médicos nesses programas... teve anos em que houve e anos em que não houve; mas já existia esse programa, e eram programas que existiam poucos no resto do mundo que ofereciam isso. Então um número grande de pessoas vinha fazer a pós-graduação conosco, pessoas da América Latina e, principalmente da Espanha, por um período muito grande; e esse curso teve momentos muito bons. Ah! Ele teve, eu diria que lá por 88 , este curso tinha uma qualidade muito elevada. Foi uma em época que nós recebíamos muitos médicos espanhóis; esses médicos espanhóis tinham uma motivação muito grande para desenvolver a pós-graduação da Medicina do Esporte. E nós conseguimos montar uma estrutura que chegou muito próximo, dentro de uma residência em Medicina do Esporte; não só tínhamos o curso, como o curso oportunizava estágios em diferentes áreas: eu oportunizava aqui e no Hospital de Clínicas; o LAPEX oportunizava; nós tínhamos um convênio com o Grêmio. Então isso criou uma oportunidade no ensino de pÓ3graduação, e até hoje eu viajo o mundo encontrando pessoas que fizeram estágio conosco e estão ocupando cargos de liderança na Medicina do Esporte em seus países. Então, essa foi uma fase muito gratificante, exatamente o momento em que nós estávamos produzindo trabalhos originais que acabamos publicando no exterior e lá dentro do LAPEX. E embora não estivéssemos vivendo um momento de recursos financeiros adequados, porque para a pesquisa nós tínhamos muito pouca coisa, o final dos anos 80 foi muito pobre para a nossa Universidade; através do curso de pós-graduação e através do trabalho muito intenso desses es- 
tagiários, nós conseguimos fazer coisas muito boas. Então, eu acho que no período, eu diria que dentro da história do LAPEX, o período mais interessante da história que eu vivenciei até 92 foi o final dos anos 80, quando nós tínhamos alta qualidade de estagiários com grande motivação e dávamos uma atenção para eles que permitia um treinamento bastante adequado.

$\mathrm{P}$ - A respeito das pesquisas que eram desenvolvidas no LAPEX desde que ele foi instalado como foram?

$\mathrm{R}$ - A primeira etapa do LAPEX, não é? Eu não chamaria de pesquisa; eu diria que nós passamos até os primeiros dez anos, vamos chamar assim... Ou melhor, primeiro vamos dividir as três etapas da minha vivência no LAPEX: a primeira de 75 a 81 , a segunda de 81 a 85 e a terceira de 85 a 92 . Então a primeira etapa eu chamaria de um momento de transferência de tecnologia. Acho que nós não fazíamos pesquisa naquela época: naquela época se buscava tecnologia dos lugares mais avançados numa área que era muito nova para o nosso meio. Quer dizer, nós não tínhamos onde aprender as coisas no Brasil, e se implantavam as novas técnicas; então se implantaram ergonometria, ergoespirometria, biópsia muscular, cineantropometria: tudo isso foi trazido. Mas eu acho que nós não fazíamos naquela época a pesquisa original, entre outras coisas porque não tínhamos formação profissional para isso: nós não tínhamos um grupo formado adequadamente para fazer pesquisa. Mas isso teve um impacto fundamental na época, e todos os trabalhos que foram publicados nessa época foram publicados no Brasil. Foram trabalhos que saíam principalmente em duas revistas: a Revista de Medicina do Esporte, que era editada aqui mesmo pelo grupo; e a Revista Brasileira de Ciências do Esporte, que veio a ser editada a partir de 78, eu acho que era feita em São Paulo, eu fui editor dessa revista alguns anos. Então essa foi a primeira etapa: transferência de tecnologia, implantar técnicas e utilizar essas técnicas de estudos descritivos nas diferentes áreas que naquela época se atuava. A segunda etapa, então, eu chamo de "nossa idade média", não é, o período em que o Laboratório parou, porque as pessoas viajaram para fazer formação, que entre $81 \mathrm{e}$ 85 houve uma retomada já com pessoas com formação acadêmica. Nesse período eu consegui produzir alguns trabalhos de pesquisa que nós publicamos no exterior, de boa qualidade, que são referenciais na literatura: o Guimarães, que nessa época produziu pelo menos um trabalho que saiu da literatura internacional; e o De Rose colaborou com algumas coisas também comigo. Então, nós, além da produção nacional que continuou num nível razoável, voltamos a participar dos congressos nacionais com uma produção adequada; nós recebemos prêmios por essa produção nos congressos nacionais. Então eu chamaria... esse é o momento no qual se passa a fazer pesquisa original no LAPEX e com contribuição de literatura internacional.

P - Quais os problemas que vocês enfrentaram na época da implantação do Laboratório?

$\mathrm{R}$ - Eu diria o seguinte: o problema maior ao longo da história do LAPEX foi assumir a identidade multidisciplinar. Eu acho que esse eu chamaria o problema fundamental do LAPEX. O LAPEX é um laboratório de investigação do exercício, quer dizer, tudo que se faz na ESEF se faz com exercício, então tudo pode ser feito investigação; e a dificuldade que se teve ao longo dos anos foi de, havendo multidisciplinaridade, entender que cada um poderia contribuir da sua forma. Sempre que se começa alguma coisa nova, essa nova situação representa, para aqueles que estão no poder, representa um desafio, uma ameaça. Fundamentalmente isso aconteceu naquela época, no início... na metade dos anos 70. E havia, inclusive, um contraste muito grande: a ESEF era um descampado, um banhado, praticamente, uma pobreza fantástica, uma escola que havia sido transformada em escola federal recentemente, fisicamente muito pobre; e o LAPEX era um laboratório de primeiro mundo. O LAPEX era pequenininho, não era muito grande, três ou quatro salas; mas o que tinha ali dentro... a sensação que se tinha é que se estava no exterior, tanto da aparência física quanto 
do material que se tinha lá dentro. Então isso gerava muita reação do sistema vigente, que era o sistema que vocês. Tem que imaginar. Hoje em dia você entra na ESEF, têm tantos doutores, tantos mestres; naquela época não tinha nem doutor nem mestre de nada, e esse contraste gerou muita reação. Então essa foi uma primeira dificuldade. A segunda dificuldade é que, também, sendo uma universidade federal, aquele grupo que vinha em formação precisava ser absorvido pela Universidade. Quer dizer, quando nós começamos, como tinham verbas externas, a minha bolsa... eu tinha uma bolsa que eu recebia da Federação Brasileira de Medicina do Esporte, a bolsa de iniciação científica, vamos dizer assim, mas eu não era funcionário da Universidade, como não era a maioria das pessoas que estavam no LAPEX; e enquanto isso outros professores da ESEF, que não estavam ligados a pesquisa, tinham a estabilidade. Então havia essa dificuldade, e essa dificuldade de integrar multidisciplinaridade existe até hoje, não é? E não surpreende, porque a Educação Física representa uma área que tem exposição a praticamente todas as outras ciências; e cada linha de ciência tem a sua linguagem, a sua maneira de trabalhar. E houve já naquela época, e depois nos anos 80 houve de novo, havia um pouco de dificuldade de as pessoas aceitarem o que os outros estavam fazendo; e eu acho que esse foi um fator importante nas dificuldades que nós tivemos esses anos todos.

P - Qual era o critério para a escolha dos coordenadores do LAPEX?

R - Olha, tanto na época que lá estive... não, eu acho que não havia um critério estabelecido: era um cargo de confiança do diretor da Escola. Eu posso dizer os fatores que devem ter influenciado a minha nomeação: o coordenador natural do LAPEX, em 1986, quando eu assumi, não era eu; o coordenador natural era o De Rose, a pessoa que deveria coordenar, o grande líder dessa área era o De Rose; mas a direção da Escola tinha alguma dificuldade de relacionamento com o De Rose e acabou optando por mim como alternativa de alguém que tinha formação, produção e que poderia con- tribuir para o desenvolvimento do LAPEX. Então, nesse sentido, o critério era esse.

P - O que nós observamos desde a formação do LAPEX até os anos 90 é que sempre estiveram médicos na coordenação; e após esse período, o Fortuna assumiu, não é?

$R$ - É, eu acho que nunca houve um critério. Na realidade... eu tenho que me lembrar, agora que tu estás dizendo... teve algum momento em que o regimento -agora tu me lembraste uma coisa correta- em algum momento no regimento do LAPEX, estava escrito que deveria ser um médico. Então isso aí até vale a pena procurar, que deve estar escrito em algum lugar, e também isso tenha participado da minha nomeação, porque eu não me lembrava, então esse é um componente. O outro componente é que a orientação do LAPEX desde o início foi de desenvolvimento da área biológica da Educação Física com um enfoque particular voltado para a fisiologia do exercício e a medicina do esporte. Essa era a vocação original do LAPEX, entre outras coisas, porque as outras áreas não faziam pesquisa, essa é que é a realidade, então houve um enfoque para a área biológica. Esse enfoque, eu acredito que tenha diminuído marcadamente a partir dos anos 90 , na medida em que tendo sido feito um investimento grande em formação de recursos humanos; e de novo eu aponto o De Rose como uma pessoa fundamental nisso, e não só na área de medicina esportiva mas em toda a ESEF: o De Rose foi uma pessoa que teve uma visão muito adequada de o que é uma estrutura universitária e oportunizou e exigiu que as pessoas buscassem formação acadêmica. No momento em que voltaram e estabeleceram suas linhas de pesquisa, elas ocuparam o espaço que obviamente mereciam; e o LAPEX hoje tem, eu imagino, essa característica multidisciplinar que ele não tinha na época. $\mathrm{Na}$ época até o final dos anos 80 , o enfoque fundamental era o biológico, mas entre outras coisas porque as outras áreas não produziam num nível que estava havendo em alguns lugares. $\mathrm{O}$ único professor de Educação Física que voltou -na realidade até nem tendo completado seu doutorado, só com o nível de mestrado- e que fez pesquisa de boa 
qualidade foi o Guimarães. No final dos anos 80 ele voltou com o mestrado -por razões pessoais, ele interrompeu o programa dele, voltou- e em 85,86 e 87 ele desenvolveu pesquisa na área de biomecânica. Um pouco que tinha naquela época, que era só eletromiografia, ele que montou. Mas os outros professores naquela época não estavam fazendo pesquisa, por exemplo, o Ricardo naquela época não desenvolveu projeto de pesquisa no final dos anos 80. Então esse foi um enfoque que para um período... Tem outra área -não sei se tu vais discutir o que é importante no LAPEX, que eu acho como característica histórica, que foi a parte assistencial do LAPEX, não sei se isso está no teu plano- a parte assistencial do LAPEX teve um período que ela teve importância até para a sustentação do LAPEX. O LAPEX não tinha a dotação orçamentária da Universidade, as verbas de pesquisa eram muito limitadas -agora eu estou falando de novo no final dos anos 80, mas isso aconteceu desde o início do LAPEX. O LAPEX oferecia um serviço de avaliação de pessoas que querem começar um programa de exercício físico; e essas pessoas faziam uma avaliação médica, faziam um teste de esforço e recebiam uma orientação -que depois foi acoplado nisso inclusive a realização do programa de exercício, não é? E isso foi... tem sido, ao longo dos anos, bastante importante porque manteve uma renda mínima para o LAPEX que permitia a ele se sustentar independente de verbas externas; e além disso esse processo assistencial foi um dos mecanismos de treinamento de estagiários do mundo todo, quer dizer, as pessoas vinham aprender a fazer isso conosco, não é? E importante colocar isso dentro de uma perspectiva histórica. Só, por exemplo, na minha área, na área de cardiologia, o LAPEX no final dos anos 70 já fazia ergonometria, que vários lugares da cardiologia não sabiam fazer. Então isso aí tem uma contribuição importante do Belmar Andrade: ele implantou um programa de ergonometria com orientação clínica e que sempre foi de muito boa qualidade. Têm algumas coisas muito interessantes que ficam difíceis de entender: nós, já em 1976, no LAPEX, fazíamos avaliações dos indivíduos que iam fazer programa de exercício, tudo com relatório computadorizado. Fica difícil imaginar que em 1976 nós já tivéssemos computador que fazia laudo de eletrocardiografia, laudo de teste de esforço; nós tínhamos ergoespirometria computadorizada tudo em 1976. Então isso que hoje parece uma coisa natural com a disponibilidade de microcomputadores, naquela época era feito quando não existia microcomputador. Nós tínhamos uma calculadora Olivetti que fazia isso, que é uma coisa de muita qualidade, não é?

$\mathrm{P}$ - Esses equipamentos chamaram minha atenção na leitura dos relatórios e outros documentos sobre o LAPEX. Até quero te perguntar sobre o orçamento, os recursos financeiros do LAPEX que possibilitaram a aquisição dos equipamentos.

$\mathrm{R}$ - Mas isso já nos 80 -eu estou falando nos anos 70- 1976 nós já fazíamos a avaliação funcional toda computadorizada. O que não existia naquela época e que eu implantei em 86 , quando eu voltei, já na era dos microcomputadores, eu implantei um banco de dados. O sistema, até 85 , era usado só com uma estrutura, impressão de laudos, informatizados, mas emissão de laudos. Eu a partir de 85 montei naquela época ainda com computador PC convencional que conseguimos numa verba minha do $\mathrm{CNPq}$, usando disquete, porque ainda não existia disco rígido naquela época- nós tínhamos todos os exames do LAPEX guardados num banco de dados de computador. Então isso aí foi uma coisa que já em 86 não era assim um avanço tão grande: era uma coisa mais ou menos natural que se fizesse; mas em 76... Então o aspecto importante... eu acho que a inovação é de final dos anos 70 , que nós estávamos muito na frente.

P - Qual era a procedência dos recursos financeiros?

R - Para o LAPEX... O De Rose pode responder melhor isso; mas eu posso dizer que na primeira etapa, nos anos entre 73 , eu diria, ou 75 , mais ou menos, e 81 ou 79 , mais ou menos, existia uma verba do Ministério da Educação específica para o desenvolvimento 
de laboratórios. O De Rose conta essa história com maiores detalhes. nanceiros..

P - Sobre a procedência dos recursos fi-

$\mathrm{R}$ - A primeira etapa -e aí o De Rose dá os detalhes- isso em princípio havia um projeto nacional de desenvolvimento específico desta área do Ministério da Educação e do Desporto; e eu não sei quais foram os anos em que essa verba entrou, mas era uma verba que se conseguiu comprar os equipamentos na época, se conseguiu manter a estrutura. E aí se construiu o LAPEX. Então aí que eu caracterizei que era um... que não era nem Bélgica: que era Estados Unidos e Índia no mesmo local, que era a ESEF naquela época. $E$ aí depois, a partir de 79, essa verba foi desaparecendo; e eu diria que, nos anos 80, o LAPEX passou a ter a sua manutenção, a verba de manutenção toda às custas da prestação de serviço da extensão, assim que funcionou, e também alguma verba que se conseguia de pesquisa, que não era de monta. E claro, aí muda, porque nos recursos humanos as pessoas estavam contratadas pela Universidade, então nós não tínhamos gastos em recursos humanos; nosso investimento em equipamento foi quase nada ao longo dos anos, final dos anos 80 não tinha verba, alguma coisa de informática que se montou. Então o LAPEX era naquele momento pobre; mas eu te diria que ele estava... a produtividade estava muito grande considerando o que se tinha naquele momento. $\mathrm{O}$ final dos anos 80 foi um momento muito favorável de desenvolvimento, mas eu tenho até um diagnóstico para dar disso, ninguém consegue manter muito tempo as coisas funcionando assim. Para que uma estrutura de pesquisa se desenvolva, é possível durante um período as pessoas trabalharem muito com muita motivação e criatividade com poucos recursos; mas para manter essas pessoas trabalhando por muito tempo, há necessidade de montar uma estrutura maior. Aí que foi a grande... Eu diria que, assim... essa trajetória não se seguiu porque não se montou uma estrutura na dimensão que motivava. Então eu estava comentando que se -eu faço estimativa- se lá por 88,89 nós tivéssemos dado um grande salto de montar um Instituto de Pesquisa do Esporte, vamos dizer assim, com excelentes condições, talvez a trajetória fosse outra. Mas, na realidade, nós continuamos com recursos muito limitados; e aí os interesses das pessoas... ainda havia pessoas no exterior também; então aí houve uma diminuição do interesse no desenvolvimento do LAPEX.

P - Então, pelo menos em termos de prédio, hoje está se construindo um LAPEX novo...

$\mathrm{R}$ - Eu diria que agora está se dando o passo, dez anos depois está se construindo -é difícil no nosso país- mas dez anos depois o LAPEX está sendo colocado na dimensão que ele deveria ter sido colocado na década passada; mas não havia esse recurso naquele momento. Então eu acho que a trajetória agora está retomada, quer dizer, agora existe um grupo grande de pessoas com formação adequada, com diferentes interesses que representam as várias áreas da ciência do esporte; e eu acho que essa perspectiva teve no final dos anos 80 , mas no final dos anos 80 eu acho que faltou esse salto: a situação econômica do País era complicada naquele momento, então não havia esse tipo de recurso.

P - Qual foi o papel do LAPEX para a Escola? Como que tu percebias um laboratório de pesquisa de primeiro mundo dentro da Escola de Educação Física?

$\mathrm{R}$ - Eu acho que o LAPEX teve um impacto fundamental na ESEF. Não tem dúvida nenhuma de que o LAPEX mudou o perfil da Escola de Educação Física da UFRGS. E difícil avaliar com precisão isso, mas eu acho que o impacto foi imenso, porque mudou rapidamente. As coisas levam um tempo para mudar, mas ele rapidamente mudou o perfil da ESEF. $O$ perfil da ESEF dos anos 70 era completamente diferente. O perfil da ESEF dos anos 70 falava de pesquisa? Não se falava: a postura era diferente, a linha de funcionamento era diferente. Eu acho que o LAPEX foi uma maneira artificial, foi plantado lá dentro, com uma estrutura que existia ali e que rapidamente tomou conta e teve um papel importante. Ou con- 
taminou várias pessoas que hoje fazem pesquisa em diferentes áreas, por exemplo, o Adroaldo: começou trabalhando no LAPEX, passou por vários setores da Educação Física e hoje tem a sua linha de pesquisa bem estabelecida; mas começou com o LAPEX; ele é a geração que começou o LAPEX. E assim têm várias pessoas que contribuíram muito e que depois... Infelizmente um dos problemas que nós temos na Universidade é que nós investimos na formação de pesquisadores, mas aí eles voltam e têm que assumir atividades burocráticas. É o caso do Ricardo, por exemplo, que também é típico da geração LAPEX: foi criado dentro do LAPEX; mas, quando voltou, na metade dos anos 80, passou a assumir progressivamente funções administrativas. Teve uma grande contribuição para a ESEF como administrador, mas como pesquisador ele não teve a oportunidade de desenvolver seu trabalho. Então eu acho que a estrutura do LAPEX foi fundamental para o desenvolvimento da ESEF: mudou radicalmente.

P - Em momento algum tu colocaste a participação dos alunos da ESEF. Havia alguma coisa dirigida para essa participação?

$\mathrm{R}$ - Na realidade, desde o início havia. Nós éramos alunos: o Adroaldo era aluno da ESEF, o Guimarães era aluno da ESEF, o Fortuna era aluno, o Biazús era aluno; todos eram alunos. Eu era aluno da Faculdade de Medicina; mas esses todos eram alunos da ESEF. O LAPEX começou fundamentalmente com o De Rose e com estudantes de iniciação científica, e essas pessoas participavam do LAPEX ativamente no desenvolvimento. Houve, por um período muito longo, um afastamento de toda essa ebulição que estava acontecendo dentro do LAPEX, da graduação da Escola de Educação Física. Eu explico o que acontecia: é que, até a metade dos anos 80 , ou melhor, até 81 , a imensa maioria das pessoas não eram professores da ESEF; nós não éramos professores da ESEF. Eu, por exemplo, até 81, não era professor da ESEF; e alguns que eram os outros professores da ESEF não tinham interesse que eles tivessem -eu estou dizendo bem claro isso- não tinham interesse de ter disciplina na gradua- ção. Então o que aconteceu por um período foi que toda essa transferência de tecnologia e esse desenvolvimento do conhecimento na área ficaram restritos à pós-graduação; não foram transferidos para a graduação por uma razão bem simples: porque não havia disciplinas de graduação. A partir de 86, quando eu voltei, aí sim eu passei a ter disciplina: foi a primeira vez que a ESEF passou a ter fisiologia do exercício. Começou em 1986, nem em 87, mas demorou um pouco. Naquele período os professores da ESEF não achavam que havia interesse nas disciplinas; e aí, no momento em que as pessoas foram absorvidas pela graduação, os professores passaram a ter disciplinas na graduação. Houve uma volta, uma aproximação novamente dos alunos da graduação; porque, até aí, eu diria que entre 75 e 85, a graduação, não tinha disciplinas ligadas ao LAPEX. Mas havia, no fundo, uma falta de interesse em alguns setores da ESEF de que essas pessoas dessem aula na graduação, Daí passaram a dar aula na graduação, e os alunos se aproximaram do LAPEX. A minha disciplina de fisiologia do exercício tinha uma prática sempre no LAPEX, desde 86; era disciplina da graduação, tinha duas turmas; e foi um período em que os alunos da graduação começaram a se aproximar. Para que haja iniciação científica... O LAPEX é um ambiente onde a iniciação científica -eu acho que é o que vocês estão fazendo, não é?é um ambiente ideal para fazer iniciação científica, mas tem que haver uma disciplina inicial: o aluno tem que fazer um primeiro contato com o professor pesquisador a partir de uma disciplina; ele passa a ter uma bolsa do CNPq, da FAPERGS; e assim por diante. Então eu acho que esse foi um erro que se cometeu no início; mas existiam razões políticas: não havia interesse da ESEF em abrir esse espaço para as pessoas que estavam trabalhando lá. Essa é a minha interpretação. Mais alguma coisa?

P - Hoje há uma discussão em que pessoas afirmam que o nosso currículo está sendo encaminhado mais para uma área biológica, está se dando ênfase maior nesta área. O LAPEX tem uma relação com esse fato?

$\mathrm{R}$ - Eu acho que o LAPEX teve um im- 
pacto importante. Se vocês estão detectando isso no currículo, de que a área biológica tem uma força grande dentro da ESEF, eu não tenho dúvida de que o LAPEX teve um impacto grande em relação a isso. Agora, eu estou apresentando uma outra linha: é que durante dez anos, por exemplo, a parte mais intensa dessa tendência biológica eu diria que é a fisiologia do exercício; a fisiologia do exercício é a primeira etapa onde o desvio passa a ocorrer. Bom, só em 86 foi aparecer a disciplina de fisiologia do exercício; então até houve um atraso, na minha opinião. Uma das coisas que vocês têm que incorporar nesse diagnóstico é que, muitas vezes, a tendência de um determinado currículo depende das capacidades das pessoas numa determinada área. Quer dizer, e eu tenho visto nos últimos anos um esforço exatamente no sentido oposto: está se mandando pessoas para fazer formação em diferentes áreas do conhecimento da Educação Física, em nível muito elevado. E eu espero que no momento... Agora fica difícil tu pegares um ambiente onde pessoas que, terminando a faculdade de Educação Física, fizeram um curso de especialização aqui em Porto Alegre. E tu colocas naquele mesmo ambiente uma pessoa que fez faculdade, mestrado, doutorado, pós-graduação; tem uma pesquisa própria... existe obrigatoriamente um crescimento aqui no serviço. Acontece a mesma coisa: uma pessoa que é produtiva, que lidera, ela acaba forçando para um lado. Mas eu tenho visto -nos últimos anos, pelo menos- o crescimento de muitas outras áreas que não são biológicas, não são necessariamente biológicas. Mas não há dúvida de que o LAPEX representou um desvio. final?

P - Tu gostarias de deixar uma palavra

R - É, eu posso. Só assim como mensagem final -eu já falei, mas quero ressaltar- eu acho que não houve, ao longo dos anos, uma capacidade da ESEF de entender a contribuição grande que foi a do De Rose. Em toda essa história, não houve um ajuste adequado para comportar o tamanho da contribuição que o De Rose fez ao longo desses anos. É difícil, porque acontecem coisas como esta: quando uma pessoa começa a brilhar muito, a área dela começa a crescer; enquanto uma cresce, e as outras não estão se desenvolvendo, o contraste fica muito grande; e eu acho que infelizmente não houve a capacidade de fazer o desenvolvimento harmônico dentro da ESEF permitindo esse crescimento grande. Eu vejo agora que, no desenvolvimento, as outras áreas estão atingindo o mesmo nível, ou seja, nós temos um grupo grande de professores qualificados, academicamente produzindo, e em diversas áreas as coisas estão se direcionando de uma maneira diferente. Mas ao longo dos anos, eu diria anos 70 e depois no final dos anos 80 , não se conseguiu fazer isso adequadamente, de conseguir entender que, por exemplo, o trabalho que um determinado professor faz tem um determinado valor na área dele; mas também tem outro trabalho que também tem valor; e houve sempre uma tendência de diminuir o trabalho daqueles que estavam produzindo. E eu acho que isso foi um problema que se teve e que agora está sendo recuperado; que, na medida em que existe mais gente produzindo, todos entendem a contribuição que está sendo feita. Então eu acho que isso tem que continuar; está sendo feita na medida em que se está construindo um laboratório de grandes dimensões, e eu acho que vai tornar a ESEF realmente o centro do País em termos de Escolas de Educação Física; mas tem que haver essa compreensão de que as áreas multidisciplinares, têm que trabalhar em conjunto, mesmo tendo suas coisas específicas. Esse entendimento é complicado dentro da ESEF. Dentro da Medicina, por exemplo, é muito simples; porque a linguagem é semelhante em todas áreas. Em Biociências, acontece a mesma coisa: têm grandes expoentes da pesquisa, têm pessoas que produzem pouco; mas a linguagem é a mesma. Na ESEF -eu acho que estou aproveitando a tua pergunta para caracterizar essa disputa entre a área biológica e a não-biológica, ou qualquer nome dado- essa disputa tem sido negativa para o crescimento da ESEF, porque tem-se usado muito mais essa competição para diminuir o trabalho do outro do que realmente para fazer os dois crescerem; e eu acho que isso tem que ser elaborado nos próximos anos: ao invés de haver competição, deve haver trabalho em conjunto e compreen- 
são de quanto cada uma das áreas contribui. Agora, isso não tem nada a ver com a filosofia do ensino: qual é o perfil do professor de Educação Física que quer se formar na ESEF, é só uma decisão que aí tem que ser feita num outro âmbito; mas na área de pesquisa precisa haver mais crescimento de todas as áreas sem haver competição negativa.

\section{P - Sobre esse Centro de Documentação} em Medicina do Esporte?

$\mathrm{R}$ - De novo isso vem da visão do De Rose em 1970, e pouco nós tínhamos em Porto Alegre. No LAPEX, uma biblioteca na área biológica, sem dúvida nenhuma, na área de medicina do esporte e fisiologia do exercício, nós tínhamos uma biblioteca invejável; e isso fazia parte do CEDIME, do Centro de Documentação em Medicina do Esporte, e era coordenado... a pessoa que fazia isso se chama Renati Sin-dermam. E eu conheço a Renati, encontro ela de vez em quando. É que ela era uma bibliotecária que montou uma estrutura; tanto é que existia toda uma literatura, a mais moderna que se podia imaginar, as revistas de medicina do esporte, eram todas assinaturas internacionais. Nós publicávamos uma revista de medicina do esporte aqui em Porto Alegre, também pelo

CEDIME. Então, do ponto de vista conceituai, o modelo que o De Rose montou naquela época é fantástico; isso tem que ser salientado. O De Rose, naquela época, não tinha formação acadêmica: ele era um médico que começou a trabalhar nessa área, só que ele tinha uma visão tão abrangente que ele alcançou todas as áreas de desenvolvimento; tanto é que se deu conta de montar uma estrutura acadêmica forte, precisava de uma estrutura de documentação sólida, e isso foi montado. Agora, de novo, desapareceu o dinheiro, houve uma queda. Então, quando nós chegamos, $\mathrm{cm} 85$, entre $81 \mathrm{c} 85$, o acervo tinha sido todo dele; não todo porque ainda estão lá mui- tas coisas, mas eu diria que pelo menos as revistas, que são fundamentais para o nosso trabalho. Tanto eu quanto o De Rose fizemos doações das nossas coleções para a ESEF, e hoje se tem uma biblioteca bastante aceitável do ponto de vista das revistas da área de ciências do esporte; mas, naquela época, a dimensão que estava se planejando era bem grande, bem grande mesmo.

\section{Entrevistado: professor Newton Fernando Fortuna}

Data de nascimento: 25/07/1 949 Entrevistadora: Profa. Janice Zarpellon Mazo Data da entrevista: 22/07/1997

Transcritor: Luciano Amaral, acadêmico do curso de Licenciatura em Educação Física da UFRGS
NEWTON FERnANdo Fortuna é Licenciado em Educação Física pela UFRGS. Mestrado pela Universidade de lowa (EUA). Foi diretor do LAPEX no periodo de 1990 a 1994. Atualmente é vicediretor da Escola de Educa-ção Física da UFRGS. ingressaste no LAPEX?

$P$ - Em que ano tu

R - Eu ingressei no LAPEX em 1973 como aluno estagiário. Eu era aluno da Escola e conversei com o De Rose, pedi para entrar. Até pressionei muito o De Rose; eu queria entrar no LAPEX, queria trabalhar aqui. E aí entrei, ingressei no LAPEX, comecei a trabalhar como estagiário. Eu era aluno de Educação Física; eu entrei na Escola em 1972 como aluno e, no ano seguinte, ingressei no LAPEX.

\section{P - Tu fizeste parte daquele grupo que}


foi fazer um curso de monitores no Rio de Janeiro?

R - Não, eu fui da segunda turma: entrou eu e o Biazús e mais umas pessoas que eu não me recordo, mas basicamente fomos eu e o Biazús que entramos juntos.

P - Tu sabes qual foi o primeiro laboratório a ser criado no Brasil?

$\mathrm{R}$ - Eu acho que foi o LABOFISE, do Rio; e o da Maria Augusta, que é o... não me lembro do nome, mas era de São Paulo. Acho que foram os primeiros... O do Maurício Rocha, esse, foi o primeiro.

$\mathrm{P}$ - Os coordenadores dos laboratórios e os pesquisadores eram médicos?

$\mathrm{R}$ - Tinha gente da Educação Física; mas basicamente quem comandava, quem criou esses laboratórios, são todos da área médica.

\section{$\mathrm{P}$ - E os recursos do LAPEX?}

$\mathrm{R}$ - Os recursos do LAPEX eram passados do Governo, que era o DED... eu não recordo disso aí... para a Federação Brasileira de Medicina Desportiva, e da Federação Brasileira é que vinha para o Laboratório.

\section{Escola?}

P - Então a verba era de vocês e não da

R - Não. Todo o equipamento, o pagamento do pessoal e o custeio... todo o recurso vinha do Governo. Era da loteria esportiva, se eu não me engano, que vinha; que repassava para a Federação Brasileira de Medicina Desportiva, eu não sei o porquê. Acredito até porque era uma relação com o esporte, era o único órgão que existia, acho que era isso. Isso quem pode esclarecer bem é o De Rose, que participou; ele pode esclarecer o porquê.

$\mathrm{P}$ - Como que tu analisas o fato de ser criado um laboratório de pesquisa dentro de uma Escola de Educação Física?
R - No início ele foi uma relação assim... complicada; eu não sei se eu te diria o termo correto... "tensa". Foram implantados esses laboratórios; e o pessoal que estava saindo para os cursos era todo pessoal novo, não eram os professores da Escola. Então houve um certo ranço, assim, por parte dos professores; porque nós, alunos, estávamos saindo, estávamos aprendendo; e eles estavam ficando para trás, eles não tinham acesso a esse tipo de tecnologia. E até a pessoa para estar aqui dentro, para ser treinada, tinha que conhecer os aparelhos; e muitos deles, alguns até por conservadorismo, não queriam dar o braço a torcer, vir para o Laboratório, perguntar coisas, então ficavam... se criou um problema: se isolaram e começaram a criticar o Laboratório.

P - Mas o Laboratório era aberto aos professores aqui da Escola?

$\mathrm{R}$ - Sim, ele era aberto... E assim que nem hoje: ele era aberto, mas se tu não estás fazendo pesquisa, não estás fazendo um projeto, tu não tens que estar aqui dentro. Agora mesmo, colocaram uma porta eletrônica ali para evitar o quê? Porque acontecia o seguinte: as pessoas entravam aqui e começavam a mexer nos equipamentos, que são delicados; então descalibram, estragam. E têm coisas até absurdas: tinha um professor, que eu não lembro o nome, mas que queria pôr os cachorros dele para caminhar na esteira, colocar os cachorros na esteira grande. É então coisa desse tipo.

$P$ - Então como que tu observas o LAPEX hoje?

$\mathrm{R}$ - Olha, eu fico muito contente com o Laboratório, assim, no estágio em que está, recebendo um prédio novo, equipamento novo. Eu fui coordenador administrativo durante a administração do De Rose, do Belmar, do Jorge Pinto Ribeiro. Depois eu fiquei de diretor no lugar do Jorge e peguei uma época muito ruim, porque o Laboratório não tinha nenhum pesquisador. Aqui dentro, quando eu fui coordenador, era só... só tinham pessoas que faziam teste... era o Belmar. Mas não existia pesquisa; 
era um laboratório de pesquisa que não fazia pesquisa: só prestação de serviço. E eu sofri muitas críticas, fui criticado; mas não é culpa minha, porque o Guimarães estava fora, o Adroaldo... tinha um monte de gente fora fazendo doutorado. Então, agora, o que é que acontece? O LAPEX hoje tem prédio, tem equipamento e tem pessoal qualificado; então eu acho que a partir de agora o LAPEX vai ser um dos melhores do Brasil, porque ele tem todo um corpo, tem equipamento e tem uma estrutura física, que é o que antigamente não tinha. Os equipamentos estavam, inclusive, todos sucateados: $90 \%$ dos equipamentos que estavam aqui foram mandados para a Divisão de Material, de depósito, porque não tinham conserto; foram equipamentos adquiridos em 1974.

P - Quando o LAPEX foi criado em 1972, como eram as instalações?

$\mathrm{R}$ - Olha, eu não tenho bem certeza, mas, se eu não me engano, ele funcionou num primeiro momento lá em cima. Isso quem pode te dizer é o De Rose. Se eu não em engano, ele funcionou lá por perto da biblioteca, isso porque lá em cima era tudo salas $i$ aula; depois ele veio aqui para esta parte aqui de baixo do prédio atual, aqui onde estamos. Aqui em cima era o judô, aqui eram os tatames do judô, e ali naquela parte era o palco; depois levantaram aquele paredão. Quando eu entrei no LAPEX, ele estava aqui em baixo, nessa área pequena; era só aquela peça onde estava o Marco e onde estava aquela parte da biomnecânica. O LAPEX era aquilo ali, e aí depois, com a chegada desses equipamentos, tudo... Até num primeiro momento, aquela esteira grande ficou lá na Brigada, porque nós não tínhamos nem onde botar, porque é uma esteira enorme; aí se pegou esta parte aqui, e depois se pegou aquela parte dali, e a esteira foi para lá. O judô saiu daqui; inclusive o professor do judô ficou muito bravo, porque tiraram o judô daqui e colocaram para o lado de lá, da parte velha, porque tinha só aquela parte onde tinha a esteira, e não tinha nada. $\mathrm{E}$ depois ele foi se expandindo, pegou a parte de cima, lá; porque lá na outra ponta funcionava o Diretório Acadêmico; na parte de baixo, onde está a secretaria atual, funcionava um bar, que depois passou a ser o almoxarifado. Então, à medida que nós fomos adquirindo equipamento, foi tomando corpo, tomando vulto, ele foi avançando em termo de área física, mas ele começou aqui em baixo.

P - Quando o LAPEX foi criado, qual era o tipo de pesquisa desenvolvida?

$\mathrm{R}$ - Ele estava todo ele, praticamente, voltado para a área da fisiologia do esporte; até porque o pessoal que deu origem a isso era o De Rose; o Belmar, que foi para o Rio; o próprio Maurício Rocha, do Rio; a própria Maria Augusta. O Maurício Rocha, se eu não me engano, era cardiologista, não tenho bem certeza; mas estava todo bem centrado nessas áreas, da cardiologia e da fisiologia do exercício, até pela formação do pessoal. Essas pessoas é que deram origem, digamos, para depois as pessoas da Educação Física entrarem na fisiologia, e foi se expandindo. E hoje, eu vejo assim, eu acho que é a forma ideal, porque hoje nós temos pessoal na biomecânica, na aprendizagem, no desenvolvimento motor, na parte da pedagogia e por parte de ensino. Hoje ele está aberto a todas as áreas, que é um ideal, quer dizer, antes não tinha... e havia uma crítica quanto a isso; mas porque não havia pessoas, no meu entender, qualificadas naquela área. Hoje já tem o Adroaldo, já está fazendo essa área. A formação do pessoal... eram todos médicos, o pessoal da fisiologia do exercício.

P - Qual era o critério para escolher os diretores do LAPEX?

$\mathrm{R}$ - Olha, num primeiro momento, eu não saberia te dizer. Tinha um regimento... $\mathrm{O}$ de Rose é que foi o fundador.

P - Quando o LAPEX foi criado, ele era um órgão auxiliar ou ele pertencia ao Departamento de Desporto?

$\mathrm{R}$ - Isso, ele pertencia ao Departamento. Ele não era, na realidade, o LAPEX: ele existia fisicamente, mas não tinha... não era uma pessoa jurídica, porque ele estava dentro de 
um... Era uma coisa, assim, totalmente absurda, porque era um órgão... era como um órgão auxiliar dentro de um Departamento, e isso não é possível. Mas isso são coisas que acontecem assim; a estrutura da Universidade é complicada. Então ele ficou dentro do Departamento até para o professor De Rose; depois nós tínhamos alguns que eram do Departamento de Desporto. Nós fomos contratados pelo professor Slolopak. Ele ficou um bom tempo como professor, com pessoas do Departamento. E houve uma época, até, que, se eu não me engano, existia um regimento ou algo assim que previa que a pessoa, para ser diretora do LAPEX, tinha que ser médico, e médico do quadro da Universidade; e, na época, o único médico do quadro da Uniyersidade era o De Rose. Tinha algo desse tipo. Então, depois, houve até uma certa resistência, e algumas pessoas queriam que o LAPEX passasse a ser órgão auxiliar; e, sendo órgão auxiliar, o diretor seria cargo de confiança da direção da Escola. Então, a partir do momento em que ele passou a ser órgão auxiliar, a direção da Escola passou a indicar o diretor do LAPEX.

P - Atualmente o LAPEX é um órgão auxiliar da Escola sem dotação orçamentária?

R - É, sem dotação; porque era isso aí o problema da época: deve ter dotação, não deve ter dotação. É que se ele tivesse dotação orçamentária, o cargo de diretor não seria de confiança do diretor da Escola: seria escolhido ou alguma coisa desse tipo. Então tecnicamente, também... uma porque ele não tinha recurso, previa no estatuto que ele tinha que ter arrecadação. Não sei, eu não me lembro mais, mas tinha algo no estatuto da Universidade que previa... ele tinha que ter um requisito para ter dotação orçamentária; e, tendo uma dotação, o cargo de diretor não seria de confiança da direção da Escola. Na idéia da Escola, ele tecnicamente não podia passar a ser um órgão auxiliar com dotação orçamentária. E a preocupação era essa: ele em sendo órgão com dotação orçamentária, o diretor não seria mais um cargo de confiança da direção da Escola, ele seria escolhido entre membros ou tipo assim; com a escolha pelo diretor da Escola, então ele sem do- tação orçamentária, ele passaria a ser cargo de confiança da direção.

P - Vocês fizeram muitas pesquisas e trabalhos na área de avaliação de atletas?

R - Sim. Eu não trabalhei muito com pesquisa, eu ajudei um pouco. Eu, no início, quando entrei aqui, basicamente o que nós fazíamos... nós aprendemos, vamos dizer assim, a ser operadores de máquina: esse era o primeiro estágio. Quando entrávamos, nós aprendíamos a mexer em todos os equipamentos. Logo em seguida eu passei a fazer parte da administração: era eu que controlava as contas, tudo. E aí eu fui me afastando do projeto de pesquisa; eu eventualmente ajudava na monitorização de teste, alguma avaliação, mas eu não estava envolvido com pesquisa. Eu já fui para... eu era o prestador de contas: eu que fazia todo o controle das contas e dos recursos que entravam.

P - Tu sabes por que o Governo Federal criou este laboratório e os outros laboratórios no País? Quantos laboratórios foram previstos inicialmente?

R - É, eu não lembro bem isso aí, mas eu sei que eles tentaram, uma vez, implantar um laboratório até em Recife. Eu até aproveitei nós tínhamos um campeonato de vôlei, e eu estava trabalhando com a seleção gaúcha como preparador físico, e era em Recife... o LAPEX é que pagou essa passagem- e aí eu fui visitar o laboratório que estavam implantando em Recife. Era assim: uma sala, uma bicicleta ergométrica, um monitor e mais nada -muito reduzido. Então não tomou vulto a coisa: ficou reduzida basicamente a Porto Alegre, Rio de Janeiro e São Paulo. Acredito eu que até, naquela época, também, eles estavam... foi depois da Copa de 70, o Governo queria investir no esporte; então eu acho que foi uma política governamental. Eu não tenho... não me lembro de mais dados; eu nunca me envolvi com esse tipo de coisa.

P - E o curso de Especialização em Medicina do Esporte? 
$\mathrm{R}$ - $\mathrm{O}$ curso surgiu depois, eu não me lembro bem exato quando, mas existiu. É como existe hoje, digamos assim: o pessoal do curso recebia parte do treinamento aqui dentro; então o que é que acontecia? Em nível de América do Sul, esse pessoal que vinha da Venezuela, da Colômbia, do Equador, do México... teve gente da Espanha, uma época, aqui dentro... esse pessoal não tinha esse tipo de experiência nos seus países, com esses equipamentos, com esteira, com teste de esforço. Então o que é que acontecia? Isso foi... O Rio Grande do Sul era um pólo; então as pessoas vinham para cá, vinham da Argentina, do Uruguai... Nós tínhamos, praticamente, acho que todos os países da América do Sul. Inclusive nós tivemos médicos aqui, eram médicos que vinham; às vezes vinham professores de Educação Física, um chileno que era professor de Educação Física veio e ficou um tempo aqui. Era isso, não é? O De Rose, por ser coordenador do curso de Medicina Desportiva e por ser o diretor do Laboratório, também aliava as duas coisas. E o certo era isso: as pessoas tinham treinamento prático dentro do Laboratório, tal como hoje tem o curso de treinamento, que tem algumas aulas aqui dentro; como algumas disciplinas da Escola... A função do Laboratório era dar apoio ao ensino, à extensão e à pós-graduação.

$\mathrm{P}$ - O que tu sabes sobre o CEDIME, Centro de Documentação em Medicina do Esporte, no LAPEX?

R - É que eles tinham um Centro, eu não em lembro bem disso aí, mas eles editaram... tinha até uma revista que era a revista da Federação Brasileira de Medicina Desportiva... tinha uma revista, que até era o doutor Algayer que a coordenava, mas tinha uma revista... a biblioteca deve ter ainda alguma.

P - Qual a relação do LAPEX com a Federação de Medicina?

R - A Federação repassava os recursos para os laboratórios, e os laboratórios... Tinha o seguinte: para que tu fosses membro da Federação de Medicina Desportiva, tu tinhas que ter feito o curso de Medicina Desportiva. En- tão, assim: o Belmar é especialista em medicina do esporte, então ele é membro da Federação Gaúcha, já foi presidente da Federação Gaúcha; o De Rose também já foi presidente da Federação Brasileira, da Federação Internacional. Então o que é que acontecia? Eles, médicos, especialistas em medicina do esporte, através da Federação, eles tinham... eles editavam essa revista.

P - O curso de Medicina do Esporte era só para médicos ou era aberto a outros profissionais?

$\mathrm{R}$ - Na época, $90 \%$ eram médicos. Teve uma época em que teve um ou dois fisioterapeutas; mas a grande maioria eram médicos.

\section{P - Os professores de Educação Física} não podiam cursar?

R - Não. Não porque tu tinhas de ser médico; o curso era de Medicina do Esporte. Mais adiante é que a pessoa de outra área fazia junto, mas não fazia as cadeiras da área médica, e depois, parece, recebia um certificado de especialista em Ciências do Esporte ou alguma coisa assim. Mas tu não podes receber o titulo de Médico Especialista em Medicina Desportiva se tu não fores médico: o pré-requisito era ser médico.

P - Gostarias de dizer mais alguma coisa?

R - A criação do Laboratório, do laboratório de Porto Alegre, deu origem ao surgimento de diversas clínicas de prevenção e reabilitação de cardíacos. As primeiras clínicas de Porto Alegre foram a Physis, que era do Rubens Rodrigues; a Prevencor, que hoje é do Belmar; a Cardioclínica, o Adroaldo trabalhava lá... O Ricardo, por exemplo, trabalhava na Physis; o Guimarães trabalhava na Prevencor... Então todo esse trabalho surgiu com o pessoal treinado no LAPEX; então isso aí é que eu acho importante: a criação desses laboratórios. Acredito que no Rio e em São Paulo tenha acontecido a mesma coisa; mas aqui em Porto Alegre eles deram origem a esse trabalho de preven- 
ção e de reabilitação através da prática regular e orientada de exercício físico. Essas clínicas tinham a parte de prevenção e reabilitação; então a reabilitação, por exemplo, tinha que ter a presença de um médico, era obrigado a ter. Tinham pacientes infartados, pacientes com problemas sérios; e tinha também o trabalho de prevenção, que tem até hoje. Então acho que isso é um dado fundamental: a partir do LAPEX isso se disseminou, não é?

\section{P - Mais alguma informação?}

R - Por volta de 1972, teve um Congresso Mundial de Medicina do Esporte em Porto Alegre, inclusive ele foi realizado na Assembléia Legislativa, eu não «ei. bem, mas o De Rose pode te dizer bem exato qual foi o congresso, foi feito lá na Assembléia Legislativa. O LAPEX teve participação; teve curso aqui no ginásio inclusive. Foi um congresso mundial: tinha pessoal da Alemanha e de diversos países do mundo.

\section{Entrevistado: professor Antônio Carlos Stringhini}

\section{Guimarães}

Data de nascimento: 23/08/1952

Entrevistadoras: Profa. Janice Zarpellon Mazo e

Cínthia Denise Bordini

Data da entrevista: 1 4/06/1 999

Transcritora: Cínthia Bordini, acadêmica do curso de Licenciatura em Educação Física da UFRGS e bolsista PIBIC/CNPq.
ANTÔNIO CARLOS STRINGHINI GUIMARÃES é Licenciado em Educação Física pela UFRGS em 1973. Curso de Mestrado na Universidade de Iowa (EUA) em 1981. Doutor em Biomecânica pela Universidade de Calgary (Canadá) em 1993. Foi diretor do LAPEX no periodo de 06/ 07/1994 a 20/12/1996. Atualmente é diretor da Escola de Educação Física da UFRGS.
$\mathrm{P}$ - Em que ano ingressaste como professor aqui na ESEF?

R - Ingressei como professor colaborador em 78; era uma espécie de professor substituto.

$\mathrm{P}$ - Na época em que tu eras aluno da ESEF, já existia o Laboratório?

R - No terceiro ano, se estou bem lembrado, em 1973, na metade do ano, em julho, o professor De Rose reuniu um grupo de alunos e algumas outras pessoas -o Belmar que era médico da universidade; inclusive algumas pessoas que não tinham vínculo com a Universidade ainda ou que já tinham sido alunose nós fomos ao Rio de Janeiro. Deve ter sido em julho de 73, que foi antes de eu me formar, acredito que tenha sido nessa época. Fomos ao LABOFISE, que era o Laboratório de Fisiologia do Exercício da Federal do Rio de Janeiro. Que me conste, foi o primeiro laboratório a ser criado e que realmente na época tinha uma estrutura de pessoal, recursos humanos, de recursos materiais e que atuava intensamente na área. Ficamos lá durante quatro semanas e fizemos um curso chamado Curso de Pesquisadores em Educação Física. Não tínhamos mestrado em Educação Física no Brasil ainda, então esse curso visava a preparar pessoal para trabalhar na área de pesquisa. Interessante que esse curso não era só de conteúdos específicos da fisiologia, ele nos deu uma formação básica: tive-

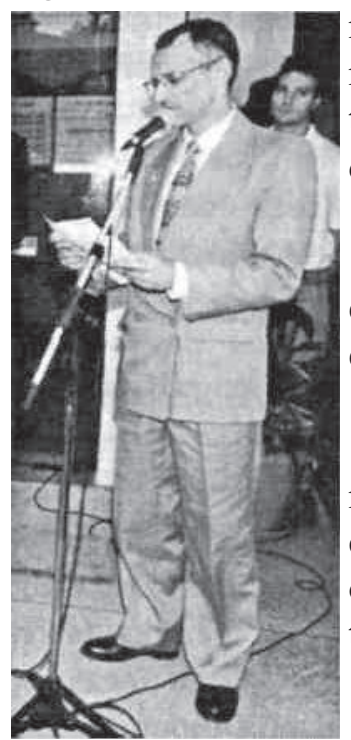
mos aulas de física, de matemática, de antropometria e assim por diante.

$\mathrm{P}$ - Como era a estrutura do LAPEX na época da sua criação?

$\mathrm{R}$ - Esse foi o momento que eu tenho como a criação. Talvez o professor De Rose tenha movimen- 
tado um pouco, mas eu tenho essa data como um marco, pois até então não existia nenhuma sala. Aí começou justamente lá no ginásio mais antigo da Escola, onde atualmente há salas de aula; ali que eu tenho algumas imagens de termos algumas reuniões. Eu entendo que ali tenha sido, na prática, iniciado. Acredito que o professor De Rose tivesse iniciado já alguma coisa com o professor Setineri, acredito, mas eu não participei disso aí; mas mesmo que isso tenha havido, é uma coisa muito próxima a essa data.

\section{LAPEX?}

$\mathrm{P}$ - Tu começaste como estagiário do

$\mathrm{R}$ - E, nós éramos voluntários. Tinham alguns colegas de turma: alguns deles permaneceram na Escola, outros não. Dos que permaneceram, temos o Ricardo, o Adroaldo, eu e o Belmar. E têm outras pessoas que continuaram suas carreiras fora da Universidade, colegas professores: Hélio Becker, de Novo Hamburgo; Schroeder, que atualmente está no interior do Estado; João Ricardo Magni, que é médico atualmente do Grêmio; acho que o Peroni participou do grupo mais adiante; professor Heron Beresford, uma pessoa que marcou muito a preparação física no Rio Grande do Sul, um cara que tem impacto na preparação física -até então a preparação física no Rio Grande do Sul era muito... assim, sem observar princípios científicos; e o Heron foi uma das pessoas que me marcou e marcou, acredito, vários desse grupo; uma pessoa que estudava na Educação Física; ele buscava a origem da fisiologia, o porquê do treinamento e coisas desse tipo- e outras pessoas que esteja me esquecendo no momento.

P - Qual a estrutura organizacional do LAPEX na época da sua criação?

$\mathrm{R}$ - Basicamente ele não tinha uma estrutura: o que existia era o professor De Rose, que pelo que entendo foi quem criou de fato o Laboratório. O professor De Rose teve a idéia de criar, com a experiência dele, já na época internacional, ele criou esse Laboratório de fato. Mas não tinha uma estrutura de direção como hoje, por exemplo, se nós criarmos um órgão dentro da Universidade: ele era o chefe porque ele criou, ele teve a idéia, ele trouxe. E, naturalmente, como não tinha também o status de um órgão auxiliar, não havia pesquisadores: havia um grupo que começou a trabalhar.

P - Qual a procedência dos recursos financeiros do LAPEX?

$\mathrm{R}$ - Eu sei que os recursos vinham de Brasília, eu acredito que vinham... Teríamos que ver qual era a sigla correta, se era DEDMEC... Bom, fundamentalmente, nós éramos bolsistas voluntários nesse período aí: não recebíamos. E depois, mais adiante, no final do ano de 73, alguns dessa turma se graduaram: o Ricardo, eu, o Adroaldo, o Hélio Becker, o Schroeder; esses cinco pelo menos. Nós permanecemos ali. Em alguns momentos nós tínhamos, não posso dizer que era uma bolsa, mas às vezes nós recebíamos algum valor simbólico ou de uma bolsa; mas às vezes passavam-se os meses sem se receber absolutamente nada. Então era uma atividade muito mais voluntária e criava uma angústia muito grande; porque na medida que nós já estávamos formados, e nós gostávamos daquilo que estávamos fazendo e não queríamos abandonar; por outro lado aquilo não nos ajudava a nos sustentar. Então alguns assumiram atividades dando aulas em colégios do Estado, como no meu caso; alguns de nós no interior; e assim foi.

P - Como era determinada a escolha da coordenação do LAPEX?

$\mathrm{R}$ - E, enquanto um órgão dessa natureza não tenha um vínculo com a Universidade de um órgão auxiliar, ele pode permanecer com a mesma direção, como é o caso de vários laboratórios na Universidade. Nós temos a idéia de que a direção de um laboratório necessariamente muda; e não é verdade. Existem laboratórios dentro da Universidade cuja chefia é vitalícia: enquanto o professor existir ele permanece. $E$ acho que essa talvez seja a regra; mas a maioria desses laboratórios não tem esse status de órgão auxiliar. Então era uma coisa que era 
vinculada ao Departamento de Desportos, não é? Eu não me lembro. Aí permaneceu o professor De Rose, e depois veio o Belmar, depois o Jorge... e todos eles médicos. Te confesso que não me recordo como foi feito isso aí. Eu tenho uma desconfiança de que, talvez, depois de um determinado momento, o Laboratório estivesse vinculado à direção da Escola, mas não tenho certeza. Como é que havia a mudança? Por que passou a haver a mudança da direção? Porque passou a haver uma ingerência maior no Laboratório; por que o Laboratório se constituía de certa forma numa fonte de poder dentro da Escola; por que ele dispunha de recursos, ele tinha acesso a recursos que eram consideráveis na época. Então muitas vezes a Escola tinha menos recursos, Eu não entendo muito bem, na época eu era aluno, não convivia com esses dados. Então eu acho que o Laboratório começou a despertar um certo interesse -na minha avaliação subjetiva. Aí não sei bem como se deu isso aí, honestamente não me lembro de como é, por que passou; imagino que ele estava vinculado à direção da Escola. Depois a vinda do Fortuna começou assim, porque o Laboratório foi-se expandindo. No início, basicamente, se trabalhava com pesquisa. E eu me lembro, abrindo um parênteses, que um dos primeiros projetos que nós fizemos, se não foi o primeiro, foi uma avaliação de composição corporal de jogadores de futebol, que foi um trabalho muito interessante, em que nós medimos... O De Rose trouxe essa tecnologia, essa metodologia de dobra cutânea, que não existia; realmente foi uma inovação. E nós, no campeonato brasileiro -que não tinha esse título ainda, não lembro como chamava- todas as equipes que vieram ao Rio Grande do Sul, a Porto Alegre, praticamente todas foram avaliadas. Acho que tínhamos uma amostra de 110 ou 210 jogadores, uma amostra bem considerável das melhores equipes do Brasil. Nós medimos vários jogadores de expressão da época; inclusive Pele foi avaliado, me lembro que o percentual deu dez vírgula... ponto alguma coisa e tal. Então era fundamentalmente pesquisa no início. Born, depois de um determinado momento, não recordo exatamente quando, passou a existir uma prestação de serviços em que era feita a avaliação. Eu acho que o Labo- ratório teve uma repercussão enorme, grande mesmo, que muitos desconhecem nessa área da avaliação, regional e nacionalmente. Acho que o De Rose e o Belmar são pessoas que marcaram, sem dúvida. Hoje em dia qualquer clínica que se vá faz uma avaliação ergométrica; mas o que pouca gente sabe é que quem trouxe essa tecnologia para cá foram essas pessoas. Eles trouxeram o Laboratório e eram também vinculados a clínicas particulares, e assim que se começou a se fazer no Rio Grande do Sul a avaliação ergométrica e eletrocardiografia em esforço. A UFRGS deve ser o primeiro local onde isso foi executado. Passou a haver, então, prestação de serviço; existiam alguns convênios, me parece que existia alguma coisa com a SOGIPA, não sei em que moldes. Então começou a existir a necessidade de uma administração do Laboratório. Do ponto de vista administrativo, passou a existir essa necessidade; então se criou a figura de um coordenador administrativo. Então, num determinado momento, surge o Fortuna como pessoa que passou a fazer a parte administrativa, antes de assumir a direção geral do Laboratório. Me recordo -talvez isso tenha acontecido com o Jorge, não sei se foi antes- eu sei que o Jorge fazia mais a parte científica, cuidava do que era o Laboratório até então; e o Fortuna que cuidava da parte interna administrativa, parte contábil do que já existia. Depois, o que naturalmente aconteceu... Havia uma predominância de médicos nessa época, porque eles realmente tiveram a iniciativa disso aqui, acho que em outros lugares no Brasil também -Maurício Rocha e outras pessoas... Depois o que aconteceu foi o seguinte: surgiram os cursos de mestrado, o pessoal da Educação Física foi-se qualificando e naturalmente foi também assumindo a direção desses laboratórios.

P - Que tipos de trabalhos eram desenvolvidos no Laboratório?

$\mathrm{R}$ - Era um Laboratório que começou na parte de antropometria: nós trabalhávaos basicamente com composição corporal, medidas de dobra cutânea, com somatotipia, também. O professor De Rose trouxe o professor Cárter, da Universidade de San Diego, que na época 
era uma pessoa de muita expressão internacional, porque ele tinha um método de somatotipo que ele adaptou de Sheldon, que fazia através de fotografias; e o Cárter adaptou para determinar o somatotipo de Sheldon através de medidas antropométricas. Isso foi amplamente difundido no Brasil, porque envolvia uma tecnologia simples e barata: bastava um antropômetro e um compasso. Juntamente com a parte de ergonometria, inicialmente com medidas indiretas, testes em esteiras, testes em bicicletas e eletrocardiografia em esforço. Esse é o início do Laboratório.

P - O Laboratório recebeu muitos professores estrangeiros?

$\mathrm{R}$ - Eu sou muito ruim em datas, mas têm várias pessoas: teve um da Alemanha -não lembro do nome, mas é muito conhecido; esteve o Cooper e, junto com ele, um fisiologista de expressão internacional -está me falhando o nome dele agora, mas é um nome que podemos resgatar, pois tem livros editados- era quem coordenava toda a parte de pesquisa do Cooper, ele esteve aqui e deu uma mão muito grande; esteve aqui também Peter Kevini, uma das maiores autoridades na área de biomecânica na época; e outras pessoas que eram expoentes internacionalmente. Acho que em 1975 tivemos um congresso grande em Porto Alegre, realizado na Assembléia Legislativa sobre medicina desportiva; ali participaram várias autoridades.

P - Qual a importância do Laboratório para a Escola de Educação Física?

$\mathrm{R}$ - Acho que o LAPEX foi uma peça fundamental, e vou usar dois termos: pesquisa e pós-graduação. Como eu falei, nós fomos fazer um curso que pretensamente em um mês formava pesquisadores em Educação Física ou Ciências do Esporte, algo assim. Com o decorrer do tempo -porque nós realmente não sabíamos o que estava acontecendo internacionalmente, nós estávamos "de fraldas", iniciando nessa área mais biológica- a partir de um certo ponto, nós identificamos uma necessidade muito grande de sair, de estudar, de nos pre- parar realmente para pesquisa. Esse, acho, foi um marco histórico, porque desencadeou um processo de pós-graduação das pessoas que estavam vinculadas à Escola. Sem dúvida isso foi marcante; nós fomos os primeiros no mestrado: o Ricardo, o Fortuna, eu, o próprio De Rose; não me lembro da ordem. Pela necessidade criou-se um problema; então nós pensamos que, se realmente pretendêssemos desenvolver pesquisa aqui, precisaríamos em primeiro momento fazer mestrado. Obviamente fizemos mestrado; e aí, dentro de uma perspectiva mais internacional, nós vimos que o mestrado era só o início e que seria indispensável que se fizesse o doutorado. Do meu ponto de vista isso foi marcante; acredito que os outros laboratórios desencadearam também isso. Na minha avaliação subjetiva, as primeiras pessoas do País a fazerem mestrado vêm dessa área da fisiologia, do biológico, do treinamento. Eu me lembro do Valdir Barbanti da USP; acredito que se pegarmos os dez primeiros ou quinze, vários deles estão ligados a isso aí e à pós-graduação; porque a pesquisa está vinculada à pós-graduação. A implantação do Laboratório deu um caráter científico à área do treinamento, particularmente, que até então era uma coisa feita intuitivamente por pessoas inclusive que não tinham nenhuma formação, nem em Educação Física; então o pessoal começou a se preocupar. Houve uma ênfase muito grande na área do treinamento; o Gilberto Tim e principalmente o Heron se destacaram. Principalmente o Heron nos marcou pela atitude dele de buscar, de ler, estudar: ele queria saber o porquê; pois, até então existia uma série de coisas estranhas que eram feitas, particularmente no futebol, e ele começou a questionar até que ponto eram válidas. Depois veio o Gilberto Tim. E uma pessoa que, embora não vinculada ao Laboratório, teve uma tarefa muito importante aí, mas ele era muito discreto, foi o professor Bugre Lucena, que era uma pessoa que conhecia muito treinamento e trabalhava muito próximo ao Gilberto Tim, só que ninguém sabia. Inclusive na preparação de uma das seleções brasileiras, quem auxiliava o Gilberto Tim no programa da seleção era o professor Bugre, só que o nome dele jamais apareceu. O professor Gilberto Tim procurava o 
professor Bugre, que era professor de JudôTreinamento) da Escola, e o Bugre ajudava muito o Gilberto a preparar; mas o Bugre sempre foi uma pessoa muito discreta, não tinha nenhum vínculo com seleção brasileira, não gostava desse tipo de coisa: fazia aquilo voluntariamente. Então o Laboratório teve esse impacto: começamos a ser presenteados com palestras; a ter acesso a artigos, livros, só em estrangeiro -hoje em dia há publicações em português, mas naquela época não existia. Então o professor De Rose trazia esse material todo. Isso é um marco, sem dúvida... com conseqüências políticas, porque isso fortaleceu muito a área biológica; e as outras áreas, vamos supor, pedagógicas se deram conta, na minha avaliação, de que a área biológica tinha crescido demais; e houve um certo combate entre elas, porque houve esse movimento, de fato, de conhecimento que foi trazido e naturalmente cresceu.

P - O que tu sabes sobre a implantação dos outros laboratórios?

$\mathrm{R}$ - Hoje têm mais disseminados: tem laboratório na Universidade de São Paulo (USP); em Brasília; na Universidade do Estado de Santa Catarina, na Universidade Estadual de Pernambuco; tem também em São Caetano -alguns mais fortes numa área do que noutra. Até se nós fizermos uma relação sem anotar, corremos o risco de cometer uma injustiça muito grande; de repente a Universidade Federal do Paraná também tenha. Mas os primeiros, pelo que me consta, foram Rio de Janeiro; a USP... De fato, as condições em que o de Porto Alegre foi criado eu não conheço. $\mathrm{O}$ professor De Rose tinha um acesso, um vínculo grande com o Ministério. Nas atribuições dele, num determinado momento, ele assumiu a Secretaria Geral ou a Presidência da Federação de Medicina Esportiva. Então ele era uma pessoa projetada nacionalmente. Tinha uma projeção nacional através do futebol: ele era médico do Grêmio, acredito que ele tenha iniciado a sua carreira no Grêmio; ou se destacou na imprensa -um médico de clube de futebol sempre é uma pessoa de expressãoentão ele conquistou um espaço ali. Realizou esse grande simpósio em 75 , e aquilo teve uma repercussão muito grande.

P - Como é a relação da Escola com o LAPEX, e como é feita a escolha dos diretores do Laboratório?

$\mathrm{R}$ - Atualmente isso é um processo muito simples. Não existe a opção de que a escolha dos diretores do LAPEX seja feita de uma forma diferente de como ela é; porque, a partir de uma determinada data, o LAPEX passou a ser um órgão auxiliar e, como tal, ele se enquadra dentro das normas maiores do estatuto da Universidade. E a direção de um órgão auxiliar é cargo de confiança da direção da Escola; então o diretor da Escola é eleito e só a ele compete a nomeação do diretor do LAPEX, com a homologação do Conselho da Unidade, que é o órgão supremo. Então é uma escolha. Dos outros órgãos auxiliares, como, por exemplo, o Centro Olímpico, também; diferente dos departamentos, das comissões, que são feitas através de eleição.

P - A contribuição do LAPEX para a pesquisa, a extensão e a pós-graduação foi destacada no teu depoimento. E a relação do LAPEX com o ensino?

$\mathrm{R}$ - Dentro dessa perspectiva, eu acho que o LAPEX se tornou hoje aquilo que particularmente acreditava que ele deveria se tornar. Quero fazer um registro: no meu ponto de vista, o nome LAPEX hoje é inadequado; mas, por uma questão de tradição... Eu também particularmente sou contra. O que é o LAPEX hoje na Escola? Na verdade, ele é um centro de pesquisa da Escola de Educação Física da UFRGS e ponto final. Como tal, ele contempla atividade de pesquisa. E quem está vinculado à atividade de pesquisa? Todos aqueles que têm projetos de pesquisa aprovados em alguns dos órgãos de fomento, as fundações - $\mathrm{CNPq}$, FAPERGS, CAPES, Pró-Reitorias, esse tipo de coisa- com seus respectivos estudantes de pósgraduação associados aos projetos, no nosso caso estudantes do mestrado, que desenvolvem lá seus projetos; e com seus respectivos bolsistas de iniciação científica, envolvendo, 
portanto, a graduação. Isso no âmbito da pesquisa. No âmbito da graduação, sem dúvida alguma ele se constitui... ele desempenha as atribuições previstas pelos regimentos maiores da Universidade no que diz respeito a um órgão auxiliar: ele tem que apoiar o ensino, a pesquisa e a extensão, e faz exatamente isso. Nós temos várias disciplinas, não saberia enumerar, que são administradas com o apoio e lá dentro do Laboratório. Vou começar com as que estou mais familiarizado e até mais vinculado: a cinesiologia, a biomecânica, a fisiologia do exercício, medidas e avaliação, toda a parte das disciplinas do Departamento de Ginástica e Recreação que trabalham com postura e assim por diante. Outro aspecto que eu acho importante é que tenho a sensação de que hoje nós conseguimos na Escola, pelo menos parcialmente, superar um "ranço" que existia entre uma área biológica com uma outra área mais ligada às ciências humanas. Eu entendo que isto seja indispensável para a Educação Física, dentro da UFRGS: crescer como um todo. Eu não acho que o crescimento possa se dar em partes; eu não acredito que tenha que crescer a área biológica, e depois tu paras a área biológica e cresces a área pedagógica ou outra área que seja... não: eu acho que as coisas têm que acontecer simultaneamente. Acho que o LAPEX assumiu essa tarefa, porque ele não é uma entidade superior. O que ele é? Ele é um local onde se congregam professores da Escola de Educação Física que desenvolvem pesquisa e ponto final. Que tipo de pesquisa? Não interessa; qualquer tipo de pesquisa que seja desenvolvida na Escola só tem um lugar: é o Laboratório ou o apoio do Laboratório. Então ele respalda as teses de mestrado, os projetos de pesquisas, independente da área. Mudou muito a conotação pela qual ele foi criado, não que estivesse errado: ele começou por onde existia conhecimento, onde existiam pessoas interessadas. Naturalmente, naquela época não iria ingressar com interesse pedagógico se começou pelo pessoal da medicina: eles alavancaram uma coisa que estava relacionada com a área de interesse deles; posteriormente veio um grupo mais interessado... mais ligado à área pedagógica. Então, hoje ele é um centro. Quais as atribuições de um órgão auxiliar?
Apoiar a pesquisa, ele o faz; apoiar o ensino tanto de graduação quanto de pós-graduação; e a própria extensão, através de prestação de serviços, de avaliações: a Escola pode se sentir plenamente tranqüila com relação a essas tarefas. Outro grande mérito que eu acho que a Escola tem hoje em dia é que o Laboratório e a pós-graduação trabalham juntos. Nós conseguimos criar isso com alguns objetivos, quais sejam, potencializar, apoiar projetos de pesquisas; facilitar teses de mestrado; num futuro muito próximo, próximo mesmo, as teses de doutorado; os projetos dos professores. Isso é uma coisa de fato, não só dita, não só colocada no papel; na medida em que, inclusive do ponto de vista de recursos que são de um setor, são investidos no Laboratório; porque a pósgraduação enxerga que lá é um ponto que permite a execução de alguns projetos, e viceversa. Essa é uma grande conquista da Escola e vai ser indispensável para o sucesso do doutorado que está sendo implantado agora.

\section{Entrevistado: professor Mario Roberto Generosi Brauner}

Data de nascimento: 07/01/1953 Entrevistadora: Profa.

Janice Zarpellon Mazo Data da entrevista: 01/1 0/1 997

Transcritor: Luciano Amaral, acadêmico do curso

Licenciatura em Educação Física da UFRGS

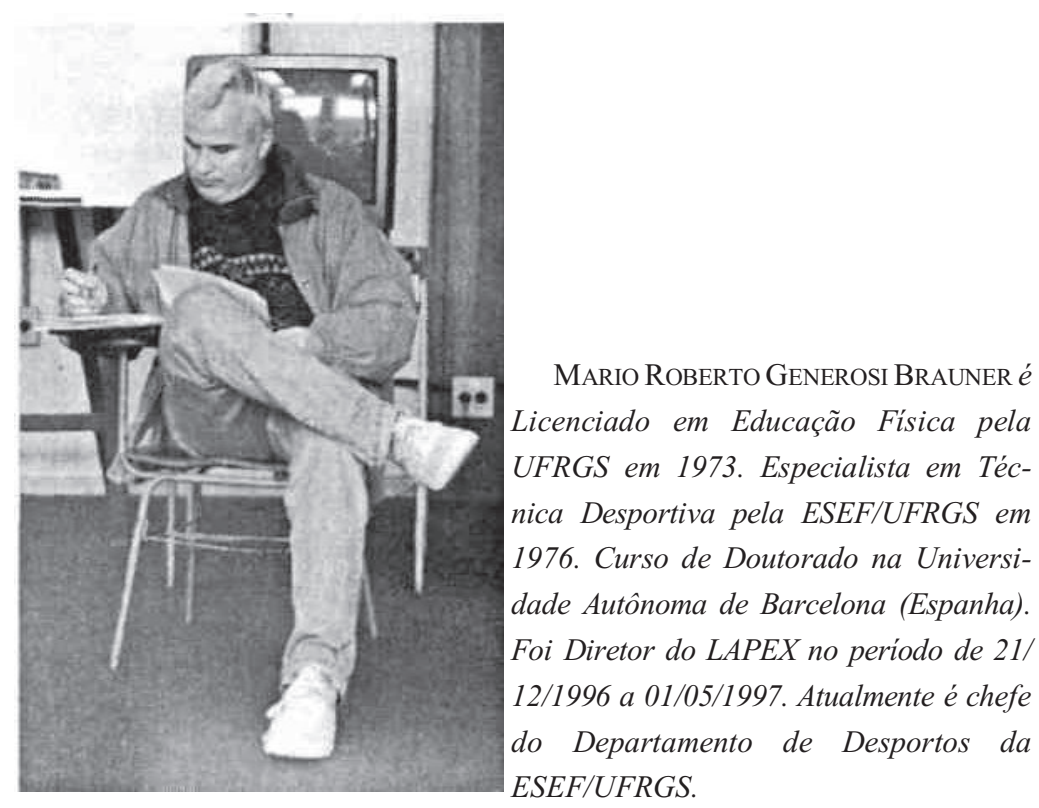


P - Comente a tua formação acadêmica.

$\mathrm{R}$ - Comecei a licenciatura aqui na Escola de Educação Física da UFRGS em 1971 e concluí em 1973. Mais adiante, em 76, fiz um curso de Técnico Desportivo na mesma Escola, na modalidade de basquete; eu já estava trabalhando. Fui treinador de todas as categorias e coordenador do Departamento de Basquete da SOGIPA de 84 a 88 . De agosto de 85 até março de 86, fiz um curso de Especialização em Basquete em Moscou -vinculado ao Comitê Olímpico Internacional- num sistema de colaboração por ser um dos povos mais avançados no basquete e no esporte de maneira geral. Estava trabalhando na SOGIPA e na Escola Estadual Júlio de Castilhos. Iniciei aqui na Escola como professor em 79; hoje sou professor adjunto 3, sempre trabalhando nas disciplinas de basquete (fundamentos, técnicas avançadas e, mais recentemente, com reformas de currículo, em técnicas de ensino). Em 89 fiz uma ruptura essencialmente prática a partir de treinamento desportivo e fui tentar algumas respostas também no campo da teoria: saí para fazer doutorado em Barcelona, onde fiquei de janeiro de 1990 até abril de 1994; desenvolvi uma tese na área da pedagogia do esporte, relacionada com programas de iniciação desportiva, essencialmente sobre a teoria e a prática dos professores.

\section{LAPEX?}

P- Em que período foste diretor do

$\mathrm{R}$ - Eu estive no cargo de 21/12/1996 até 01/05/1997.

P - Embora tenha sido um período curto, qual tua visão do LAPEX naquele período?

$\mathrm{R}$ - Eu fui pego de surpresa, porque, mesmo estando no Laboratório diariamente e sabendo da existência de todas as atividades cotidianas, eu tinha pouca vivência, na medida em que eu ocupava as instalações, mas não participava diretamente de qualquer atividade específica do Laboratório. Foi um período de transição: em fevereiro o professor Vicente Molina estaria retornando de seu doutorado em
Barcelona e deveria assumir o cargo. Meu papel foi puramente figurativo: eu apenas assinava e encaminhava documentos, mas não tinha nenhum poder de decisão.

$\mathrm{P}$ - Tu poderias me relacionar algum problema que enfrentaste no LAPEX?

$\mathrm{R}$ - Não, pois naquele período curto -eu acho que até compreendo o que acontecia em função do que havia sido combinado- o professor Guimarães nunca deixou que as coisas transcendessem, principalmente as coisas negativas. O Laboratório funcionou normalmente; se bem que nos meses de janeiro e fevereiro sempre há um recesso, porque coincide com as férias acadêmicas. Mesmo assim, todos os problemas maiores e as questões administrativas que faziam o funcionamento do Laboratório aconteceram no gabinete da direção da Escola. Então, eu não tive problema funcional e tampouco administrativo nesse período.

P - Que lugar ocupa o LAPEX na ESEF e no âmbito da Educação Física brasileira?

R - Sem dúvida representa a possibilidade de desenvolver, sob o ponto de vista da ciência, nossa atividade física e esportiva. Desde 1971, período em que o LAPEX foi implementado, este representou um espaço de ponta na produção do conhecimento dentro da nossa área; isso durou uns cinco anos, enquanto estava sob a direção do De Rose. Com o passar do tempo, não sei dos motivos exatamente, ele foi perdendo um pouco do protagonismo. Antes da minha saída para o exterior, de 1985 em diante, o Laboratório não transcendia as próprias atividades, não tinha um espaço relevante dentro das atividades da Escola e foi perdendo terreno. Quando voltei, em 1994, já tinha retornado também, do seu doutorado, o professor Guimarães; na direção da Escola estava o professor Petersen: senti que tinha sido dado um novo impulso. Em 94 tivemos algumas reuniões buscando uma adequação no regimento do Laboratório: o Guimarães procurava criar um espaço dentro do Laboratório para que todos tivessem como desenvolver os seus projetos, suas linhas de investiga- 
ção. A partir de 1994, senti um interesse muito forte pelo Laboratório; e, mais recentemente, surgiu a oportunidade de montar, na Escola de Educação Física, um dos Centros de Excelência do País.

P - Qual é o papel do LAPEX no contexto atual?

$\mathrm{R}$ - Na medida em que não estou convencido de que o Laboratório seja o único pólo da Escola... Houve um momento em que o Centro Olímpico teve mais peso, não só político, mas com relação à dotação orçamentária, superando a da própria Escola. Desviar um pouco daquilo que seria a preocupação original da Escola, um curso de licenciatura. Então eu fico um pouco preocupado com o desdobramento das outras possibilidades de atuação do nosso campo, porque a área biológica, que é aquela com maior tradição no Laboratório, está tranqüilamente estabelecida como nossa área. Meu questionamento está centrado nas reais possibilidades de desenvolver, dentro do LAPEX, as outras áreas do conhecimento que não somente aquelas relacionadas com a biologia, a fisiologia, a biomecânica, etc. a partir das Ciências Sociais e Humanas; e é onde eu me vinculo: na pedagogia, não do esporte especificamente, mas da atividade física esportiva. Precisamos encontrar uma forma de reunir os interessados sem contrariar os interesses da área de fisiologia, da área biológica. Não podemos deixar de nos preocupar com a formação de professores e em especial com a graduação: esse deve ser o eixo principal da Escola de Educação Física da UFRGS.

P - Uma palavra para finalizar.
$\mathrm{R}$ - É preciso reconhecer o esforço da professora Janice e sua equipe de trabalho: o resgate da história do LAPEX deve marcar os seus 25 anos de existência; é importante que tenhamos um registro daquelas pessoas que construíram o Laboratório. Como professor há quase 20 anos nesta Escola, eu vejo o Laboratório como uma das áreas que mais podem projetar a Escola tanto em nível local, regional e até nacional, não necessariamente apenas como Centro de Excelência voltado para o esporte, mas com a pesquisa vindo reforçar a formação dos futuros professores, treinadores desportivos. Através do Laboratório, poderíamos conseguir, também, um espaço para discussões entre os profissionais, um espaço de promoção de eventos específicos no campo da atividade física e desportiva.

\section{Entrevistado: professor Vicente Molina Neto}

Data de nascimento: 11/01/1952 Entrevistadora: Profa.

Janice Zarpellon Mazo Data da entrevista: 03/1 0/1

997 Transcritor: Luciano Amaral, acadêmico do curso de Licenciatura em Educação Física da UFRGS

P - Em que período tu ficaste na direção do Laboratório?

R - Bem, eu assumi a direção do LAPEX logo que retornei do Doutorado, a convite do Guimarães, mesmo sem ter a formalização legal desse ato. Isso aconteceu a partir de $20 \mathrm{de}$ fevereiro de 1997, logo após o carnaval.

Vicente Molina Neto é Licenciado em Educação Física pela UFRGS em 1975. Especialista em Lazer e Recreação pela ESEF/UFRGS. Mestre em Educação pela Faculdade de Educação da UFRGS. Doutor em Educação pela Universidade Autônoma de Barcelona (Espanha) em 1996. Foi diretor do LAPEX no periodo de 02/05/1997 a 15/07/1997. Atualmente é coordenador do programa de pós-graduação em Ciências do Movimento Humano da UFRGS.

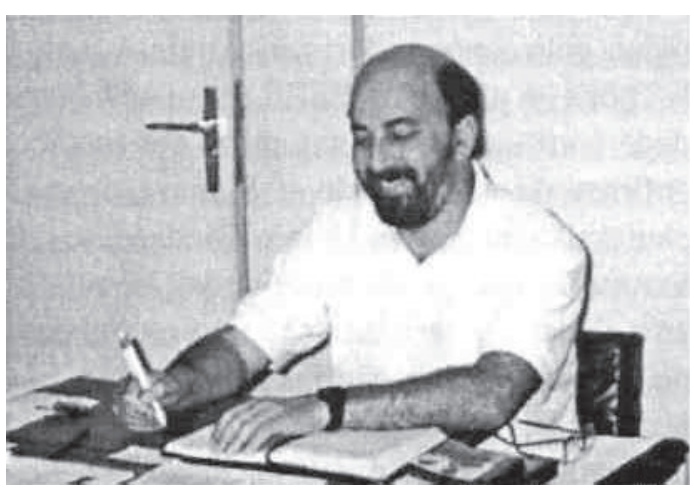


$\mathrm{P}$ - Tu te lembras da portaria?

$\mathrm{R}$ - Tenho a portaria sim: eu fiquei, se não me engano, até 15/07/1997, quando eu fui dispensado pela portaria da reitora.

P - Como tu observas a relação entre Laboratório e a Escola de Educação Física?

$\mathrm{R}$ - Teve uma fase, antes, que eu tinha uma visão do Laboratório, que foi quando eu era aluno e também professor da Escola, foi antes de eu fazer o doutorado. Bom, a minha perspectiva naquela época... até eu tinha muitas críticas ao Laboratório, principalmente pela forma como ele estava inserido na Escola naquele período que foi implantado, que eu era aluno e depois vim a ser professor da Escola. Então eu via muito o Laboratório como um organismo autônomo dentro da Escola de Educação Física, que funcionava... era bastante fechado à comunidade de professores da Escola. $\mathrm{E}$, nas reuniões de que eu participava, sempre tive a oportunidade de fazer essas críticas, porque era um organismo bastante fechado: tinha um grupo de pessoas que fazia pesquisa aqui dentro, mas o resto da comunidade acadêmica ou escolar, vamos dizer assim, não tinha... não sabia o que acontecia. Para entrar aqui -começava que tu tinhas umas barreiras psicológicas primeiro, que hoje não mais existem- tinha um balcão e uma porta que o sujeito para entrar, para ultrapassar aquela barreira e se interessar pelo LAPEX, tentar estabelecer uma curiosidade sobre o que eram aquelas coisas ali, era praticamente impossível. Bom, aí eu fui para o doutorado e tal, e voltei. Antes de ir para o doutorado, eu participei do processo eleitoral aqui da ESEF, que foi um processo que realmente virou o jogo aqui na ESEF. A ESEF se caracterizava pelo conservadorismo extremo e, naquela época -e não só na ESEF, mas na Universidade como um todo- nas mãos dos médicos; enfim, toda essa questão aí. E com o processo eleitoral do professor Hélgio Trindade, se conseguiu fazer uma chapa de oposição bastante articulada; e aí se fez também um movimento na Escola de Educação Física. Foi interessante: a ESEF foi a unidade que teve o maior percentual de votos para a oposição na eleição do Hélgio. Foi realmente significativo, tanto é que o professor Cassei foi convidado a ser próreitor da comunidade acadêmica exatamente pelo percentual de votos; porque ele era o único que não era da chapa. Porque o acordo que havia é que todos os pró-reitores... todos os membros da chapa que não fossem indicados para reitor seriam pró-reitores; e o único que foi Pró-Reitor sem ter sido membro explícito da chapa foi o Cassei, tamanha representatividade da nossa vitória aqui dentro da Escola. E aí nós fizemos campanha e tal, e o processo do Ricardo Petersen foi o mesmo; então o Ricardo é conseqüência desse movimento, dessa necessidade que nós tínhamos de um grupo de professores articulado e com uma visão mais progressista e comprometida com a Escola; e o Ricardo foi nesse processo. Então, vê bem, claro que se estabeleceu uma série de metas para o LAPEX, para o Centro Olímpico, para a ESEF; se estabeleceu uma plataforma e tal. Bom, e aí eu fui para o doutorado; e claro, quando eu estava lá fora, terminou o mandato do Ricardo; e o processo eleitoral que elegeu o Guimarães, que é o atual diretor, claro que seguiu essa mesma linha, um comprometimento político, uma linha mais aberta. Enfim, eu estava em Barcelona terminando o meu doutorado. Eu estava a par do que estava acontecendo aqui, tanto é que recebi o convite para ser diretor do LAPEX na campanha do Guimarães lá em Barcelona; então eu estava terminando a tese e já tinha recebido o convite, não é? Porque era garantir uma proposta mais aberta, uma proposta progressista e, claro, o Guimarães, que é um sujeito sério; e eu votaria nele se eu estivesse aqui e participaria do trabalho, como havia participado. E aí o que aconteceu? Eu vim, comecei a trabalhar e... bom, o LAPEX, dentro da Escola, se tornou um auxiliar desse processo e, pelo trabalho do Guimarães, pelo trabalho do Ricardo, foi um órgão que se destinou... que começou a apoiar o trabalho da Escola; e com isso veio a pós-graduação. O LAPEX, de uma certa forma, se abriu, não é? Então todas aquelas pessoas, aqueles professores que tinham um trabalho de investigação e que tinham um trabalho de pesquisa, o Laboratório foi aberto a eles; então isso aí representou um grande avanço na política do Laboratório, no meu pon- 
to de vista. Mas aí tu vais me perguntar assim: "Bom, mas então por que tu saíste?" Então, não é? Não, aí a questão entra no plano, vamos dizer assim, das estratégias administrativas para se conseguir o plano de governo que nós acreditávamos; e aí nós esbarramos na questão de metas. Então, na verdade, claro, eu era um pesquisador do ramo, vamos dizer assim, qualitativo; e o grande volume de pesquisa que é feita aqui é do ramo quantitativo e biológico. Então eu, na verdade, comecei a sentir... a me sentir assim... para legitimar um discurso da pesquisa, tipo assim, de que a pesquisa qualitativa é incipiente aqui dentro do Laboratório. Então eu achei por bem, para ser coerente com os fatos, sair da direção e abrir mão para a direção na qual eu acredito colocar um diretor alinhado com o tipo de pesquisa hegemônica desenvolvida dentro do LAPEX e com a metodologia para conseguir os objetivos, na medida em que a nossa diferença é em questões de métodos para se lograrem os objetivos maiores da Escola. Porque todos nós queremos "históricos", e outros trabalhos de investigação dentro das ações são num número muito reduzido, porque ficam muito mais num esforço de cada pesquisador do que realmente numa política de investigação do LAPEX. Então isso era uma coisa que me inquietava um pouco quando eu estava na direção, porque era assim: o sujeito se sentia um pouco como a "Rainha da Inglaterra", que tem um certo fascínio, um certo charme o cargo, mas tem pouco poder político no estabelecimento de diretrizes políticas para a investigação da Unidade. Porque, na verdade, o que é que acontece? A pesquisa fica centrada no interesse do investigador; e o diretor não tem poder nenhum para distribuir os recursos para a pesquisa, ele não pode nem tirar recurso de uma coisa e botar na outra; porque quem financia as pesquisas são as agências externas à investigação. A ESEF não tem dinheiro para dizer assim: "Bom, agora nós vamos investir neste tipo de pesquisa e financiar este projeto." O diretor do LAPEX jamais pode fazer isso; então está tudo bem, tem um certo charme e tal, mas, do ponto de vista prático de desenvolvimento de pesquisa, a função dele é um apoio, vamos dizer assim, de garantir a sala e estamos conversados. Então eu vejo nesse sen- tido. Bom, então a política que tem de investigação dentro do LAPEX está muito centrada nos investigadores; e quando os investigadores atuais do LAPEX, a maioria são aqueles oriundos dos cursos de mestrado nos Estados Unidos, aprenderam a fazer pesquisa dentro de um modelo de investigação, o modelo que vive dentro do LAPEX é esse, é o modelo que eu me referia antes. Então o que isso quer dizer? Eu vejo perspectivas agora, com o novo prédio e tal, se tentarem outros tipos de pesquisa. Mas é como eu digo: a pesquisa não é só... não basta só tu chegares e dares uma sala para o sujeito: não, é uma série de apoios institucionais para que o investigador se sinta estimulado a esse tipo de pesquisa não só pelo reconhecimento, enfim, pela valorização desse tipo de pesquisa, como também, claro, passa pelas condições de material.

P - O LAPEX tem um prédio novo. Isso significa uma nova proposta para este Laboratório de Pesquisa do Exercício?

R - Não, quer dizer, sim e não. Na verdade, quando eu pensava que agora, com a inauguração desse prédio, era a oportunidade primeiro para nós abandonarmos essa idéia construída em cima de um "laboratório", porque a própria terminologia, o próprio sentido da palavra já te induz a um pensamento sobre um tipo de pesquisa. Então, ainda que se queira preservar a tradição, aquela memória romântica do tempo quese fazia pesquisa com todo o esforço, lutando contra um e contra todos; ainda que se queira manter este termo, esta marca "LAPEX" é este local de fazer pesquisa. Sob meu ponto de vista, ele deveria ser transformado num centro de investigação, exatamente para dentro... É que é muito difícil para essas pessoas compreenderem... Essa questão de linguagem é importante, não é? Bom, estão aí estas ciências que estão construídas em cima das linguagens: semântica e outras tantas, não é? Então, quer dizer, mas o pessoal, vamos dizer assim, que detém o controle do poder de decisão sobre isso tem um pouco de resistência. Mas no meu ponto de vista seria isso: esse lugar de pesquisa seria um grande centro de investigação onde estariam controlados todos os mode- 
los de pesquisa -os tradicionais e os emergentes. Assim, o diretor ou alguém que se proponha a estabelecer uma política, trataria, vamos dizer assim, de apoiar não só com materiais, mas também com favorecimentos no plano institucional das pesquisas não-tradicionais dentro da ESEF. Não sei se dá para tu entenderes o que eu estou dizendo.

$\mathrm{P}$ - Sim, aquelas que ainda não se legitimaram, não é? Que têm que construir um caminho.

R - E se encaminhando, não passa só pelo lugar: é como aquele pessoal que quer resolver os problemas da educação garantindo vagas para os alunos nas escolas; e isso não resolve problema nenhum da educação. É a mesma coisa que querer resolver os problemas do LAPEX dando um lugar para o pesquisador ali dentro; e, claro, a pesquisa qualitativa ou essas pesquisas emergentes precisam de outros apoios, porque qualquer coisa que venha... que esteja de encontro a ela é um grande abalo; ao passo que, num paradigma já legitimado, qualquer percalço não surte efeito, entendeu? Então eu acho isto: não é só colocar um pesquisador dentro do LAPEX que vai desenvolver um tipo de pesquisa, sei lá, colocando todos esses meios materiais; mas também passa pela questão de reconhecimento na questão da divulgação. Bom, do próprio reconhecimento da comunidade, o respeito, muitas vezes tu ouves aqueles pesquisadores mais tradicionais dizerem que esse tipo de pesquisa é pouco científico; então reconhecer, pelo menos se interessar, olha... saber que a pesquisa qualitativa e que os outros... os enfoques emergentes, vamos dizer assim, precisam de um outro tipo de tratamento, mais do que somente dar lugar para o pesquisador, não é?

Entrevistado: professor Ricardo Demétrio de Souza Petersen

Data de nascimento: 09/07/1 951 Entrevistadora: Profa. Janice Zarpellon Mazo Data da entrevista: 08/08/1 997

Transcritora: Cíntia Brino, acadêmica do curso de

Licenciatura em Educação Física da UFRGS
P - Comenta a tua formação acadêmica.

$\mathrm{R}$ - Eu tenho o curso de Licenciatura em Educação Física, que comecei em 1971 e concluí em 1973; tenho curso de Especialização em Atletismo, que realizei em 1975 aqui na Escola de Educação Física da UFRGS; fiz o meu curso de mestrado, que iniciei em 1979 e terminei em 1981; e em seguida, no mesmo ano, no segundo semestre, eu iniciei o meu curso de doutoramento e concluí em outubro de 1984.

P - Em que áreas sã o mestrado e o doutorado?

$\mathrm{R}$ - O mestrado foi na área de concentração de aprendizagem motora; e a segunda, biomecânica. No curso de doutorado, a primeira

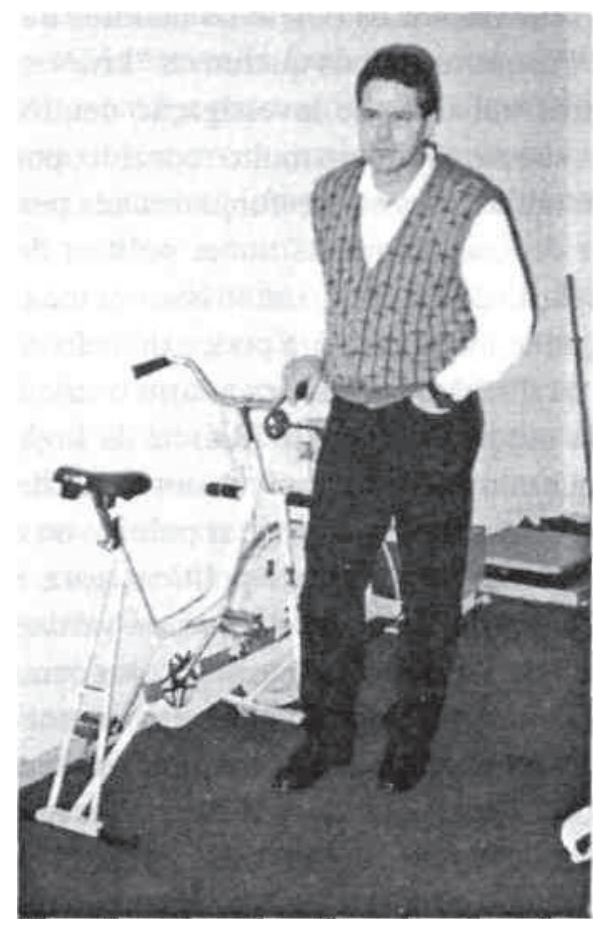

RicARdo DEMÉtrio de SouZA PETERSEN é Licenciado em Educação Física pela UFRGS em 1973. Especialista em Atletismo pela ESEF/UFRGS em 1975. Mestre em Aprendizagem Motora pela Universidade de Iowa (EUA) em 1981. Doutor em Desenvolvimento Motor pela Universidade de Maryland (EUA) em 1984. Realizou estudos de pós-doutorado na Universidade de Maryland (EUA), em 1998 e 1999. Foi diretor do LAPEX no ano de 1997.. 
área foi desenvolvimento motor; e a segunda, aprendizagem motora.

\section{P - Como foste trabalhar no LAPEX?}

$\mathrm{R}$ - Na realidade, eu fui indicado pelo professor Werner, o Peixinho", para fazer parte de um grupo de alunos que seriam os estagiários do LAPEX; então foi por indicação do professor Werner.

$\mathrm{P}$ - Na época tu eras aluno do curso de licenciatura?

$\mathrm{R}$ - Eu era aluno e estava no terceiro ano em 1973.

P - Então começaste no LAPEX como estagiário?

$\mathrm{R}$ - É, na realidade, nós fomos para o Rio de Janeiro fazer um curso de pesquisadores em Educação Física, se não me engano esse era o nome do curso, na Escola de Educação Física da Universidade Federal do Rio de Janeiro, na Ilha do Fundão. Esse curso era coordenado pelo doutor Maurício Leal Rocha; foi um curso em que nós tivemos as primeiras noções de pesquisa e do que estava sendo feito na área. Foi um curso bom, para a época, que nos deu uma boa visão do que era um laboratório de pesquisa do exercício, no caso; e isso nos deu, então, a base para iniciar todo o trabalho no Laboratório.

P - Por que foram criados os laboratórios de pesquisa do exercício nas escolas de Educação Física? Tu tens alguma informação sobre isso?

R - Não. Na realidade, nós não sabíamos muito bem o que estava acontecendo, até acredito que nós nem questionássemos muito; mas a impressão, quer dizer, o que nós entendíamos é que era uma forma de se apoiar o esporte de alto rendimento, de que essa era a intenção do Ministério; enfim, há exemplos de outros no mundo. Esses laboratórios de alguma forma seriam direcionados para fazer a pesquisa na área do esporte; e isso basicamen- te é o que foi... vamos dizer assim, foram os primórdios das pesquisas no LAPEX.

P - Como tu caracterizarias o tipo de pesquisa desenvolvida no LAPEX na época da sua fundação?

$\mathrm{R}$ - As pesquisas eram, basicamente... Eu me lembro que nós trabalhávamos muito com a parte de cineantropometria -diagramas de Shelton, tipos corporais (mesomorfo, endomorfo, ectomorfo) e percentagem de gordura; então se faziam alguns trabalhos nessa direção com jogadores de futebol. Também alguma coisa sobre consumo de oxigênio, enfim, pesquisas que, na realidade, algumas mais aplicadas, outras nem tanto, mas era por aí: eram pesquisas na área biológica. Obviamente, o pessoal que coordenava, que orientava eram médicos. Esse curso que nós fizemos lá no Rio foi com um médico que era o coordenador. Então, era esse o direcionamento das pesquisas.

P - Como tu avalias esta questão de um laboratório de pesquisa do exercício ser coordenado por médicos?

R - Eu vejo o seguinte: tem uma questão de competência. Na realidade, nós, como professores de Educação Física, não tínhamos formação para esse tipo de pesquisa, não tínhamos a formação científica. O De Rose também não tinha uma formação científica, não é? Ele foi o primeiro coordenador, foi o fundador do Laboratório. Na realidade, nenhum de nós tínhamos. O que acontecia? O De Rose eventualmente trazia alguém para nos dar orientação, como fez esse curso lá no Rio de Janeiro. O De Rose viajava muito, como continua viajando, e lá fora ele via algumas pesquisas, algum equipamento novo e alguma metodologia nova. Enfim, ele procurava trazer isso para nós; mas era passado assim... não de uma forma sistemática, não havia reuniões formais: era uma coisa muito "passado de boca" mesmo. Então, nós sentíamos a necessidade de uma formação científica mais adequada e essa foi uma das razões por que num certo momento eu me afastei do Laboratório; pois eu sentia que nós, todos os componentes do Laboratório e inclusi- 
ve o De Rose, necessitávamos dessa formação; o que aconteceu mais tarde com todos nós ou quase todos, com aqueles que saíram para fazer mestrado e doutorado.

P - Quando vocês retornaram, como estava o Laboratório e o que mudou?

R - É, eu retornei em 1984. Fui o primeiro doutor, o primeiro Ph.D. Nós tínhamos os níveis docentes na Escola; mas, com o curso de doutorado, de Ph.D, eu fui o primeiro a voltar. E senti, obviamente, que o Laboratório estava numa situação bastante crítica: não tínhamos mais equipamentos, não se fazia pesquisa mais no Laboratório; ele estava praticamente fechando as portas. E eu tentei, com meu grupo de pesquisa, desenvolver alguma pesquisa, mas também fui "engolido" pela... vamos dizer assim, pelo trabalho -até trabalho administrativo, e acadêmico, e aulas e tudo mais- e também não consegui dar conta, até porque nós não tínhamos recursos humanos para apoiar. Então éramos os alunos e eu, num certo momento, e mais ninguém. As pessoas que... O Jorge Pinto Ribeiro já estava afastado ou se afastando da Escola, que era quem fazia pesquisa no Laboratório ultimamente; o próprio Guimarães também tinha alguma pesquisa, porém era muito pouco; e eu tentei, também, com meu grupo de pesquisa desenvolver algum trabalho. Mas foi mais tarde que realmente o Laboratório iniciou um nova fase. Isso nós estamos falando aí de 1984, 1986, 1988, por aí, não é? Nessa fase. Em 1989 e 1990, nós já começamos a... talvez, eu acho que até mais tarde, dar um novo impulso para o Laboratório. Acho que foi lá por 1992 ou 1993, principalmente, quando o Guimarães assumiu a direção do Laboratório; e aí é que, vamos dizer assim, houve um... foi dado um novo impulso para o Laboratório.

P - Qual a relação do Laboratório com a Escola de Educação Física?

$\mathrm{R}$ - Uma das coisas importantes é que os três últimos coordenadores eram professores de Educação Física: isso, de certa forma, dá um outro enfoque para o Laboratório. Por que isso? Bom, por que o Laboratório começa a se abrir para outras áreas; não fica tanto na área, vamos dizer assim, biológica, que normalmente é a mais tradicionalmente conduzida pelos médicos. E, já na minha volta do doutorado, eu via que o Laboratório teria que se expandir, teria que abrir para outras áreas. Naquela época e, posteriormente, na implantação do mestrado, nós fomos buscar professores de outras áreas. Os próprios professores da Escola que nunca tinham se motivado a participar do Laboratório porque lá se fazia pesquisa biológica começaram a participar das atividades, de algumas atividades do LAPEX. Com isso começou a se delinear uma nova visão de Laboratório; e essa nova visão começou a, vamos dizer assim, permitir que outros professores, professores de outras áreas, começassem então a se motivar e a fazer trabalhos junto ao LAPEX. Bom, a verdade é a seguinte: é que muitos de nós, pelo fato de sermos professores de Educação Física, temos uma tradição na área biológica, não é? Querendo ou não, temos uma tradição. Então, mesmo aqueles que voltaram, os primeiros a voltarem do doutorado, tinham essa vocação, porém já com uma idéia, uma concepção de Laboratório diferente até da que muitos de nós vivenciamos lá fora. Claro que hoje em dia a coisa mudou! Eu experienciei um Laboratório cujo complexo de fisiologia, de aprendizagem motora, de desenvolvimento motor, de biomecânica era bem tradicional. No entanto, nós entendíamos que o Laboratório tinha que se expandir para outras áreas; então sempre procurei atrair colegas de uma forma ou outra e acho que, de certa forma, nós conseguimos. Posteriormente, com a volta dos colegas que foram se capacitar no exterior nessas áreas -pedagogia, sociologia, enfim- foi mais fácil concretizar essa nova visão. Acho que agora a tendência é, cada vez mais, o Laboratório se tornar um... às vezes eu fico pensando se o nome "Laboratório de Pesquisa do Exercício" é adequado, talvez um "Centro de Estudos do Movimento" ou algo nesse sentido.

P - Tu és uma das pessoas responsáveis pela construção desse novo prédio do Laboratório, não é? Será que o Laboratório estaria começando uma nova fase? 
$\mathrm{R}$ - Eu acho que não; eu acho que conceitualmente não. Ele pode estar iniciando uma nova fase de área física, de equipamentos e de novas pesquisas, em função de tecnologias modernas, não é? Porém eu acho que não. Essa concepção de Laboratório já começou há algum tempo atrás, e acho que isso é importante, quer dizer, o que vai sair de pesquisa ali vai depender da competência do pessoal da área biológica, da área pedagógica, da área filosófica, da área sociológica. E aí é uma questão de competência das pessoas, das áreas que se desenvolverem, ou seja, a oportunidade está apresentada a todos. Nós, coletivamente, construímos uma nova visão de Laboratório; agora cabe a nós sermos competentes e desenvolver cada um a sua parte. Uma das grandes qualidades da nossa Escola e que nos diferencia das outras é que temos esse respeito acadêmico por todas as áreas. Acho que isso é universidade, isso é o que caracteriza. Nós não estamos aqui pensando em fazer apenas um tipo de pesquisa ou outro: não, nós temos essa liberdade acadêmica de fazer a pesquisa que nós entendemos que seja interessante. Acho que isso é de foro íntimo do pesquisador; e cabe a ele, então, desenvolver a sua área.

P - Tu tens conhecimento de que existia no Laboratório um setor que chamavam de CEDIME, que era o Centro de Documentação de Medicina do Esporte?

$\mathrm{R}$ - Eu não tenho dados, mas me lembro que isso existia. É, existia a Revista de Medicina do Esporte, inclusive.

\section{P - Que revista era essa?}

$\mathrm{R}$ - A pessoa que coordenava essa revista, se não me engano, era o De Rose. Existe essa revista; têm publicações do laboratório de medicina do esporte lá. E acho que é importante se dizer, também, que essa área teve, nacionalmente, uma contribuição muito grande no nosso Laboratório, não? O De Rose foi muito hábil nessa questão de desenvolver a medicina esportiva. Outra coisa importante também, eu não sei se tu vais me perguntar mais adiante, mas os serviços de reabilitação de cardíacos em Porto Alegre nasceram basicamente dentro do LAPEX. Eu fui o primeiro, talvez, professor de Educação Física a trabalhar no Rio Grande do Sul com reabilitação de cardíacos. Em seguida, o Guimarães e o Adroaldo também iniciaram esse trabalho. Eu trabalhava na Physis com o Dr. Rubens Rodrigues. O De Rose era sócio da Physis também, não é? Ele que me indicou para trabalhar lá. O Belmar abriu junto com outros médicos a Prevencor; o Guimarães e o Adroaldo trabalharam lá. Bom, depois vieram outros professores de Educação Física, mas essa área teve seu início com o pessoal do LAPEX em Porto Alegre.

P - O LAPEX tornou-se uma referência nacional?

R - Foi... e de América do Sul e, talvez, América Central.

P - Na Escola era obrigatório o uso do uniforme. Vocês tinham uniforme no LAPEX?

$\mathrm{R}$ - Tínhamos. Naquela época era exigido na Escola o uniforme; a Escola tinha o uniforme.

$\mathrm{P}$ - Até que ano perdurou a obrigatoriedade do uniforme na Escola?

R - Olha, eu acho que até 76 ou 77, não tenho certeza.

P - Só para os alunos?

$\mathrm{R}$ - Para os alunos. Então nós tínhamos um uniforme no LAPEX. Na realidade era um casaco igual ao que tínhamos no uniforme da Escola, porém era um azul mais claro. O da Escola era um azul marinho escuro; e esse um azul mais claro, escrito LAPEX na frente: LAPEX, se não me engano, ESEF/UFRGS; ou LAPEX - UFRGS, algo assim; ou só LAPEX. Eu tenho esse casaco ainda e tenho o prazer de doar para o Centro de Memória.

P - Naquela época, vocês eram alunos do curso de Licenciatura em Educação Física e trabalhavam no Laboratório. Havia uma certa 
diferenciação entre vocês e os outros alunos da Escola?

R - É, havia uma diferenciação, vamos dizer assim, para o lado bom e para o lado ruim. Para o lado ruim, é que nós tínhamos que fazer toda a mão-de-obra do Laboratório mesmo. Nós éramos desde... Em certos momentos nós tivemos que abrir uma sala nova onde tinha o piso especial para a prática do judô, e ali tinham pneus pregados no chão para fazer o amortecimento; então nós tínhamos que despregar aqueles pneus, varrer a sala... Quer dizer, nós fazíamos não porque éramos mandados, mas por iniciativa nossa; nunca foi uma coisa imposta, mas nós, naquele afã, naquela motivação que nós tínhamos de desenvolver o Laboratório, nós trabalhávamos. Eu me lembro que naquele dia fiquei preto e irreconhecível do pó dos pneus, da poeira da borracha. Nós também, quando tinha algum evento, carregávamos equipamentos para lá e para cá, ou seja, nós trabalhávamos de fato no Laboratório e também participávamos de coletas de dados, enfim. O lado bom é que, de certa forma, isso nos dava "status" enquanto alunos e ex-alunos também. Isso nos proporcionou, claro, uma formação diferenciada da dos colegas; inclusive nos foram proporcionados um estágio e uma viagem. Inicialmente, fomos o professor Guimarães e eu: fomos, inicialmente, a Roma; depois à Polônia, à Louvana e à Bélgica; depois a Paris -apenas de passagem, um dia só para conhecer; depois aos Estados Unidos, na Pensilvânia, na Pan Station University; e depois ao Texas visitar o serviço do Dr. Cooper, que na época estava em voga o seu trabalho. Então isso nos proporcionou uma visão mais real do que era um laboratório de pesquisa. Posteriormente, outros dois colegas -o Fortuna e o Biazús- foram também. Enfim, acho que isso foi um privilégio. Obviamente, quando nós viajamos, tínhamos hotel pago, com estadia paga; então era uma forma de nos recompensar. Nós não tínhamos salário, obviamente; não recebíamos dinheiro para trabalhar no Laboratório. Eu não me lembro de alguém ter recebido algum dinheiro: nós recebíamos, eventualmente, algum tipo de ajuda para nos manter no hotel ou coisa assim. Inclusive, o dinheiro para essa viagem... nós recebemos só passagem: os custos foram por nossa conta.

P - Quais eram as condições do LAPEX quando ele foi criado?

R - É, o Laboratório, na realidade, começou numa sala que, na época, era oposta ao bar da ESEF. A ESEF, no que se entrava no ginásio, havia uma porta à esquerda -essa porta grande de entrada para o ginásio é a mesma de hoje- à esquerda havia um bar, o bar da Dona Marina. A sala em cima do bar era do Diretório Acadêmico; no meio havia um palco, onde nós tínhamos aulas de halterofilismo, de ginástica; e na outra extremidade do palco tinha uma sala, uma das salas que o LAPEX... bom, o LAPEX engloba todas as salas do ginásio hoje, mas essa sala foi onde começou o LAPEX. Era uma salinha que tinha ali uma sala de reuniões, uma mesa grande, uma pequena biblioteca e uma salinha para o coordenador, onde ficavam a secretária e o coordenador. Posteriormente, o LAPEX foi-se expandindo; ali era muito restrito. Depois nós recebemos equipamentos, começamos a receber vários equipamentos, a expandir mais o espaço; fomos para a parte de cima, onde era o judô. O LAPEX foi-se expandido: o palco foi fechado, e se criaram novas salas. Onde era o bar se tornou almoxarifado para o prédio administrativo. Ali foi aberta a recepção; hoje em dia ali é a recepção da Escola. Então o Laboratório veio avançando lá do fundo, veio crescendo, veio vindo em direção ao lado do ginásio que dá para a parte administrativa da Escola; e, claro, por um desenvolvimento natural que foi havendo ao longo dos anos, ele tomou conta de toda aquela parte do palco no ginásio.

P - Existiam também estagiários do curso de Medicina?

R - Do curso de Medicina Desportiva.

P - Quem poderia cursar essa especialização? Eram os médicos?

R - Era o médico, sim. Eu não me lembro em que ano foi transformado, exatamente, 
em curso de Medicina e Ciências do Esporte, ou Medicina Esportiva e Ciências do Esporte; foi aí que começou a ser aberto para professores de Educação Física e médicos: os médicos recebiam um título de especialista em Medicina do Esporte ou Esportiva, não tenho certeza; e os professores de Educação Física, em Ciências do Esporte.

P - Qual era a relação de vocês, estagiários do curso de Educação Física, com os estagiários da Medicina?

R - Na realidade, nós... Havia um estágio dentro do Laboratório, e cada um de nós ficava responsável por uma área no estágio. Então, dependendo da época e de quem estava aqui, nós ajudávamos na área de cineantropometria, de fisiologia, na parte de avaliação funcional, enfim, nós éramos meio que responsáveis por algumas áreas, mas atuávamos em várias áreas. Posteriormente, quando voltei do meu doutorado, fiquei responsável por um área também, mas em seguida eu me afastei do curso de Medicina Esportiva porque achava que a minha área -depois do doutorado- não deveria estar dentro daquele curso. Entretanto, outros continuaram na parte de biomecânica, de cinesiologia e de outras áreas.

P - Qual a importância do LAPEX para a ESEF/UFRGS?

R - O LAPEX, na realidade, significou e significa muito para a Escola. Ele deu um novo status, uma nova visão... vamos dizer assim, ele se diferenciava e se diferencia das outras escolas. Por que isso? Porque o Laboratório nos proporcionou uma visão do que estava ocorrendo internacionalmente. A própria viagem, o curso que fizemos no Rio de Janeiro... Quer dizer, nós que éramos um curso de Educação Física muito voltado para a prática do "fazer pelo fazer". Aí começam a surgir, então, os questionamentos; começamos a desenvolver um espírito mais científico, mais questionador e tal. Obviamente isso deu um status para Escola: um Laboratório desses, certamente, muitas escolas no Brasil gostariam de ter recebido; e acho que esse laboratório foi a "célula", foi o início dessa nossa busca pela capacitação. Então, hoje, se fôssemos pensar nas pessoas que iniciaram o Laboratório... Eu fiz o doutorado; o Guimarães fez o doutorado; o Adroaldo fez o doutorado; o Belmar começou o mestrado, não concluiu; o De Rose fez o doutorado; o Hélio Becker resolveu ser técnico de natação -ele não investiu na vida acadêmica, mas sempre foi um estudioso da natação, uma pessoa que conhece muito a parte de fisiologia e de treinamento, certamente motivado por esse estágio no Laboratório; o Heron Beresford também fez doutorado, hoje é professor num curso de mestrado de Educação Física; o Fortuna fez mestrado. Bom, o Biazús não fez mestrado; o Caco, o Ricardo Magni também não fizeram mestrado, mas sempre atuaram na medicina esportiva. Então acho que, de uma maneira ou outra, o Laboratório foi muito importante para cada um de nós e continuará sendo; eu acho que ele tem um potencial muito grande, uma colaboração muito grande, ainda, para dar à Escola.

\section{Entrevistado: professor Marco Aurélio Vaz}

Data de nascimento: 03/08/1 964 Entrevistadora: Profa. Janice Zarpellon Mazo Data da entrevista: 20/05/1 998

Transcritora: Cínthia Bordini, aluna do curso de Licenciatura em Educação Física da UFRGS

Marco Aurélio Vaz é Licenciado em Educação Física pela UFRGS em 1985. Especialista em Educação Psi-

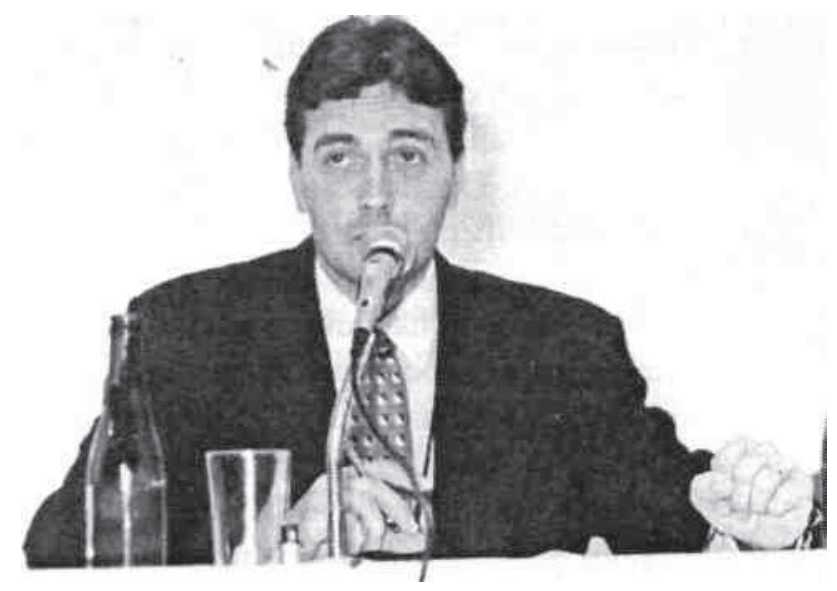

comotora pela ESEF/UFRGS em 1986. Doutor em Cinesiologia pela Universidade de Calgary (Canadá). E diretor do LAPEX desde 1998. 
P - Comenta a tua formação acadêmica.

R - ingressei na ESEF em 1983. Na verdade eu fiz vestibular para Medicina, meu pai queria que eu fosse médico -e coloquei em segunda opção. Eu tinha três opções ou quatro do que eu iria colocar em segunda opção: uma delas era Biologia; outra era Letras-Bacharelado -eu estudava línguas; a outra era Filosofia -na época eu me interessava muito por leitura. Então a minha irmã me perguntou: "Por que não Educação Física?"; e eu acabei colocando Educação Física. Então eu passei em segunda opção no meu primeiro vestibular. Por insistência do meu pai, em 1984 eu fiz novo vestibular para Medicina, mas nunca estudei convicto de que era aquilo que eu queria. Ingressei em 1983 como aluno aqui da Escola; naquela época o curso era de três anos. Eu me formei em 1985. Durante esse período da graduação, tive a oportunidade de já em 1983 ser convidado para fazer um estágio junto ao Departamento de Ciências Morfológicas do Instituto de Biociências: fiz o estágio nas férias de julho, de dois meses, e depois surgiu a oportunidade de concurso de monitoria. Então em 1984, ou 83, eu passei no concurso de monitoria, tendo sido talvez um dos primeiros alunos do curso de Educação Física que assumiu uma bolsa de monitoria junto ao Instituto de Biociências, pois essas bolsas eram reservadas principalmente para estudantes de Medicina. Junto comigo ingressaram alguns outros alunos de Farmácia, Enfermagem... Então a minha primeira atuação mais ou menos envolvido com uma questão mais didática foi ter me-tornado monitor de anatomia. Durante esse período de 84 até 1985, praticamente, eu trabalhei como monitor. Em 1984 eu conheci o professor Guimarães e disse a ele que tinha muito interesse em trabalhar dentro do Laboratório. Naquela época não tinha ainda nenhuma perspectiva para alunos de graduação trabalharem no Laboratório: existiam estágios para pessoas já graduadas, eram estágios de extensão; mas manifestei meu interesse em trabalhar junto com ele. Então naquela época ele elaborou um projeto de pesquisa relacionado com eletromiografia e exercícios abdominais; aí comecei em 84 a trabalhar com ele nesse projeto. $\mathrm{Na}$ época eu não era bolsista: eu recebi um pagamento, tipo de ajuda de custo para passagens, coisa e tal. A partir de 1985 sim, eu recebi uma bolsa CNPq de iniciação científica; foi um ano de bolsa que eu recebi. Basicamente acho que esses dois seriam os aspectos mais importantes da graduação. Em 1986 ingressei no curso de Especialização em Educação Psicomotora também aqui na UFRGS, com duração de um ano; foi concluído em dezembro de 1986. Já nesse ano, em julho de 86, fui convidado para assumir a disciplina de cinesiologia junto ao curso de Educação Física no Instituto Porto Alegre da Igreja Metodista (IPA); então eu trabalhei lá no IPA em 86, 87 e 88. Em 86 eu fui convidado também pelo professor Lino da UNISINOS para ministrar a disciplina de anatomia humana do curso de Educação Física; então elaborei o cronograma da disciplina no ano de 86 e, em 1987, ingressei na UNISINOS também como professor de anatomia humana para o curso de Educação Física. Eram duas disciplinas de anatomia humana e também a disciplina de cinesiologia, só que esta aconteceria mais tarde no curso. Também fui convidado para trabalhar com a turma da Enfermagem lá na UNISINOS, para a qual também ministrei aulas. Após concurso, ingressei na Universidade Federal de Pelotas na disciplina de cinesiologia; tive oportunidade de trabalhar lá de 89 até o final de 1991. Em 91 fui convidado por um grupo de professores aqui da Escola a me transferir da Universidade Federal de Pelotas para a Universidade Federal do Rio Grande do Sul; então me transferi e ingressei aqui em 1992, no caso não para ministrar a disciplina de cinesiologia, mas na época para ministrar a disciplina de natação; visto que os professores de natação, um estava afastado para mestrado, e o outro se encontrava na Alemanha fazendo um estágio de seis meses. Como não se tinha professor de natação, eu assumi a disciplina temporariamente. $\mathrm{O}$ fato é que na Universidade de Pelotas eles também tiveram um problema semelhante, não tendo um professor de natação para ministrar as aulas. A natação sempre foi uma paixão na minha vida: eu trabalhei também diversos anos como árbitro de natação, mas nunca me dediquei por achar que nunca conseguiria emprego nessa área. A natação sempre foi um hobby para mim, mas uma coisa que eu 
sempre gostei muito. Então tive a oportunidade de trabalhar com todas as disciplinas da área de natação em Pelotas, por não terem professor para ministrá-las, e mais a disciplina de cinesiologia. Trabalhei quase três anos com natação, inclusive também estágios em clubes. Eu tinha alguns monitores lá que acabaram trabalhando em clubes como professores de natação. Então em 92 eu vim para cá e ministrei um semestre das disciplinas natação-fundamentos e natação - técnicas de ensino. Após isso eu me afastei para doutoramento na Universidade de Calgary, onde fiz meu doutorado em cinesiologia, que era a minha área de formação.

P- Então o teu primeiro contato com o LAPEX foi na época do curso de graduação?

$\mathrm{R}$ - Exatamente. Tem mais um detalhe que eu me esqueci de mencionar: então em 84 e 85 eu trabalhei junto a esse projeto com o Guimarães. Quando terminei o curso, em 1986, no mesmo período em que eu estava fazendo a especialização, eu fiz um estágio no LAPEX, onde nós aprendíamos toda a parte de ergonometria, avaliação funcional: nós aprendíamos como monitorar um indivíduo para fazer eletrocardiogramas de repouso e de esforço; nós tínhamos seminários técnicos junto com cardiologista que explicava o funcionamento dessas curvas do eletrocardiograma, qual o significado, de que maneira poderíamos detectar problemas no coração do paciente a partir da análise desse traçado eletrocardiográfico; nós tivemos alguns seminários... Na época nós éramos professores de Educação Física e médicos que também estavam fazendo esse estágio, médicos que cursavam o curso de medicina esportiva e eram estagiários do Laboratório.

$\mathrm{P}$ - Tu tens idéia de por que foram criados não só o LAPEX, mas também os outros laboratórios de pesquisa no Brasil?

R - (Risos) 70 é ainda um pouco distante da minha época, quer dizer, época em que eu estava ainda na escola de $1^{\circ}$ grau. Não conheço a fundo a história da Educação Física no Brasil; não é uma área, na verdade, que eu tenha estudado até na minha graduação, até porque essa disciplina não existia: ela foi criada depois que eu me graduei. Então para mim faltam muitos dados históricos; mas dizem que teve um rumo, numa determinada época dos anos 70 , principalmente pela área médica, que começou a trabalhar com esses laboratórios de fisiologia do exercício; então nessa época foram criados alguns laboratórios, e o LAPEX foi um deles. Como ele foi criado, como foi montada a infra-estrutura eu não saberia dizer; aí acho que teriam outras pessoas que foram diretores e que vivenciaram a criação desses laboratórios, que participaram até do carregar objetos, que teriam mais condições de falar do que eu. O que eu posso falar mais é do LAPEX de 1997 e 1998, porque eu participei mais da construção dessa etapa nova do LAPEX do que da etapa anterior.

P - Como tu caracterizarias o tipo de pesquisa desenvolvida no LAPEX na época em que fizeste estágio?

$\mathrm{R}$ - Depende do que tu chamas de caracterizar pesquisa. Porque, quando fiz meu doutoramento, existiam dois tipos de pesquisa: básica e aplicada; hoje eu sei que as pessoas falam em pesquisa histórica, pesquisa qualitativa, pesquisa quantitativa. Então depende do que é a caracterização em termos de pesquisa.

P - Por exemplo, os campos de conhecimento que vocês estudavam, os temas dos seminários técnicos que vocês realizavam...

$\mathrm{R}$ - Eu acho que a área biológica foi a área mais... nem vou usar o termo privilegiada, porque não sei se seria um termo correto, não sei se ela foi mesmo mais privilegiada pelo fato de nós... pessoas que estávamos passando pelo processo.... Se ela foi privilegiada por alguém, foi talvez em outros níveis de decisão do País que liberaram verbas para comprar determinados equipamentos específicos; então eu acho que nós não fomos privilegiados em nada. Então na época em que eu comecei fazendo pesquisa junto com o professor Guimarães, era uma pesquisa aplicada na área biológica: estávamos estudando exercícios abdominais. A nossa pre- 
ocupação era a de passar um conhecimento científico para futuros professores e professores já formados em Educação Física que se utilizavam de exercícios abdominais nas suas aulas de ginástica na academia, no clube ou na escola, sem na verdade ter um conhecimento de causa, sem saber realmente qual exercício era bom, qual era ruim ou quais os efeitos de um determinado exercício sobre aquele aluno que estava sofrendo a ação desse exercício. Então eu acho que a nossa pesquisa sempre foi na área biológica: a minha formação é na área biológica. Então, nesse sentido, eu acho que a pesquisa que se desenvolvia nessa época dos anos 80 era uma pesquisa praticamente toda voltada para a área biológica. Eu acho que, se for feita uma revisão histórica dos artigos que foram publicados de pesquisadores que na época estavam atrelados ao LAPEX, eu tenho convicção de que $99 \%$ desses artigos vão ser na área biológica, na área médica, na área da saúde e na área da Educação Física.

P - Desde sua criação até final dos anos 80, o LAPEX sempre foi coordenado por médicos. A partir da década de 90, os professores de Educação Física assumem a coordenação/ direção do Laboratório. Como tu percebes essa situação?

R - Eu acho que essa situação é fantástica. Eu não tenho nada contra os médicos, pelo contrário: o meu irmão é médico cirurgião plástico. Eu sempre trabalhei, também, com pessoas voltadas à área médica, até por ter tido a minha formação lá no Instituto de Biociências trabalhando em volta com médicos. Tenho grandes amigos meus médicos. Mas existe um problema, acho que social, de que um médico, na nossa sociedade, é muito valorizado. Por que ele é muito valorizado? Porque as pessoas, quando estão na ausência de saúde ou se ressentem da sua saúde, procuram alguém que as ajude. Então o médico, na nossa sociedade, sempre teve um papel muito importante; a sociedade valorizou sempre o médico, muito. Enquanto que o profissional da área da Educação Física sempre foi uma figura que não era muito bem definida, que o papel não estava bem caracterizado e que fazia de tudo um pouco na sociedade. Não tinha uma identidade como o médico nem o papel curador do médico. Então, no meu entender, o médico sempre teve mais portas e caminhos abertos do que o profissional da área da Educação Física; exatamente porque a sociedade o valorizava e o valoriza, ainda hoje, bastante. No entanto, eu vejo que o papel do professor de Educação Física é tão importante ou às vezes até mais importante do que o do médico. Por quê? Porque nós temos a capacidade de fazer uma medicina preventiva, ou seja, nós, por meio de atividades físicas, podemos minimizar os efeitos da doença, evitar a incidência da doença, evitar o aparecimento da doença. Então, nesse aspecto, eu acho que a sociedade ainda não descobriu o verdadeiro papel do profissional da área da Educação Física, talvez até pela história da Educação Física. Têm muitas brincadeiras de que o professor de Educação Física servia para carregar armário em escola, essa era a função dele, ou para bater bumbo na semana da pátria, ou então para fazer todo mundo marchar: tudo uma questão militarista de que o profissional da área é só para fazer força e de que não teria uma parte intelectual. Eu acho que o que aconteceu no Laboratório reflete muito o que acontecia na sociedade. Eu vejo que dos anos 90 para cá mudou essa estrutura e acho que isso é muito benéfico, não apenas para nós professores aqui da Escola, mas para a Educação Física como um todo. Até pela situação atual do Laboratório, nós vemos que o Laboratório tem " $n$ " linhas que estão atreladas a ele, e a questão do desporto se tornou uma questão essencial hoje: a Educação Física assumiu o desporto como sendo uma das suas áreas de investigação, de trabalho, de maneira competente e eficiente. Acho que nós estamos começando, aos poucos, a tomar conta do mercado que era nosso e que nunca tivemos a competência necessária para fazê-lo. O que os médicos faziam na época do anos 70 e 80 ? Eles é que, na verdade, comandavam as equipes de futebol, de vôlei; e todas as equipes desportivas eram coordenadas muitas vezes por um médico. Ele é quem definia a questão da atividade física inclusive; e hoje não é mais assim: hoje professores de Educação Física os que definem a questão da atividade física, discutem em alguns lugares de 
igual para igual com médicos. Se delineia um pouco mais o papel do professor de Educação Física na medida em que ele tenha condição de dar uma identificação maior para as atividades do próprio Laboratório e que são mais identificadas com a nossa própria profissão. Eu acho que foi benéfica a entrada de professores de Educação Física no Laboratório que é nosso, porque é um laboratório da Escola de Educação Física. Como disse, não tenho nada contra médicos; pois no futuro podemos voltar a ter médicos, de repente, à frente do Laboratório. O único problema que eu vejo é que, sempre que os médicos estiveram à frente do Laboratório, eles não beneficiaram ou não trouxeram desenvolvimento para a área da Educação Física como poderiam ter trazido. Então existe uma problemática, até é difícil colocar em palavras, mas existe uma problemática em relação à questão do médico e do professor de Educação Física dentro das escolas de Educação Física. Só para dar um exemplo, acho que $90 \%$ dos professores de anatomia que dão aula nos cursos de Educação Física no Brasil são médicos. Isso para nós é muito ruim, porque eu, por exemplo, que trabalho na cinesiologia e quero, na verdade, que esse profissional entre na Escola com um conhecimento aprofundado dessa anatomia, ele chega com uma anatomia muito deficitária; porque o médico não tem o interesse que nós profissionais temos: ele gosta de ministrar aulas de anatomia para os médicos, porque está dentro da área dele, ele pode discutir questões clínicas associadas com questões anatômicas. Enquanto que, para nós, o ideal seria que os professores da área de anatomia fossem da área da Educação Física, porque eles vão discutir a anatomia visando à formação do nosso profissional, às nossas necessidades, ao que nós, profissionais da Educação Física, temos que conhecer para aplicar na nossa realidade. Acho que isso também seria uma mudança benéfica, isso enriqueceria muito mais o nosso curso de graduação, dando uma competência maior; porque aqui na Escola nós temos um problema grave com a questão da anatomia, e que não foi solucionado até hoje, na questão curricular. Infelizmente não depende de nós: depende de um Departamento que está nas mãos de médicos.
P - Tu foste aluno da Escola por volta de 83, 84. Como era a relação do LAPEX com a Escola e, mais especificamente, com o curso de Educação Física?

$R$ - Essa é uma pergunta de caracterizar, até porque eu nunca parei para pensar naquela época sobre qual era a relação. Eu sei que existia uma dificuldade, as pessoas colocavam, de acesso ao Laboratório. Eu não acho que a dificuldade fosse de acesso, no sentido de as pessoas entrarem no Laboratório; mas acho que a dificuldade de acesso existia na medida em que os trabalhos desenvolvidos naquela época não eram voltados exclusivamente para os nossos interesses, os nossos problemas enquanto profissionais da área de Educação Física. Se analisarmos os trabalhos do professor De Rose, são trabalhos bem na área médica do doping, coisas nesse sentido, que até possuem alguma relação com o desporto da Educação Física, mas não são da nossa área de formação. Então o que acontecia? Os trabalhos eram desenvolvidos dentro do Laboratório na área de doping do esporte e tudo mais, mas isso não tinha nada a ver com o nosso trabalho, e nós não tínhamos acesso a esse tipo de conhecimento ou até ao manuseio de equipamentos e dados porque não éramos médicos. Então, nesse aspecto, eu acho que existia uma dificuldade de competência técnica da nossa área naquela época para poder trabalhar de igual para igual com os médicos que se encontravam no Laboratório; mas também existiam "atividades que eram bem específicas, restritas da área médica que não eram da nossa área de atuação. Então, nesse aspecto, eu vejo que havia uma restritividade; mas eu não vejo, por exemplo, que o LAPEX fosse um "mausoléu dos iluminados" ou uma "casa do saber" em que outras pessoas não pudessem entrar. Por exemplo, o que eu me recordo é o seguinte: que muito poucos professores tinham projetos de pesquisa, mesmo dentro da própria área da Educação Física. No meu entender, isso em parte era muito pela nossa incompetência técnica, mais do que por qualquer outro motivo. 